\title{
First evidence for a Vibrio strain pathogenic to Mytilus edulis altering hemocyte immune capacities
}

\author{
Ben Cheikh Yosra ${ }^{1}$, Travers Marie-Agnes ${ }^{2}$, Morga Benjamin ${ }^{2}$, Godfrin Yoann ${ }^{2}$, Rioult Damien ${ }^{3}$, \\ Le Foll Frank ${ }^{1, *}$
}

\author{
${ }^{1}$ Laboratory of Ecotoxicology- Aquatic Environments, UMR-I 02, SEBIO, University of Le Havre, F- \\ 76063, Le Havre Cedex, France \\ 2 Ifremer, SG2M-LGPMM, Laboratoire de Génétique et Pathologie des Mollusques Marins, Avenue de \\ Mus de Loup, 17390, La Tremblade, France \\ ${ }^{3}$ Laboratory of Ecotoxicology- Aquatic Environments, UMR-I 02, SEBIO, University of Reims \\ Champagne Ardenne, Campus Moulin de la House, F-51100, Reims, France \\ * Corresponding author : Frank Le Foll, email address : frank.lefoll@univ-lehavre.fr
}

\begin{abstract}
:
Bacterial isolates were obtained from mortality events affecting Mytilus edulis and reported by professionals in 2010-2013 or from mussel microflora. Experimental infections allowed the selection of two isolates affiliated to Vibrio splendidus/Vibrio hemicentroti type strains: a virulent 10/068 $1 \mathrm{~T} 1 \quad(76.6 \%$ and $90 \%$ mortalities in $24 \mathrm{~h}$ and $96 \mathrm{~h}$ ) and an innocuous 12/056 M24T1 (0\% and 23.3\% in $24 \mathrm{~h}$ and $96 \mathrm{~h}$ ). These two strains were GFP-tagged and validated for their growth characteristics and virulence as genuine models for exposure. Then, host cellular immune responses to the microbial invaders were assessed. In the presence of the virulent strain, hemocyte motility was instantaneously enhanced but markedly slowed down after $2 \mathrm{~h}$ exposure. By contrast, hemocyte velocity increased in the presence of the innocuous 12/056 M24T1. At the same time interval, 10/068 1T1 invaded hemocytes and was more rapidly internalized than the innocuous strain. Extracellular products (ECPs) prepared from 10/068 1T1 cultures significantly inhibited phagocytic activity while 12/056 M24T1 ECPs had no effect. Furthermore, the pathogenic strain and its ECPs inhibited oxidative burst unlike 12/056 M24T1 strain/ECPs which enhanced ROS production. Taken together, our results suggest that the mussel pathogen 10/068 1T1 may escape immune response by altering hemocytes functions.
\end{abstract}

\section{Highlights}

- Isolation of a Vibrio strain pathogenic to the blue mussel. - Two differentially virulent Vibrio strains were GFP-labeled. The virulent strain altered hemocyte motility and quenched ROS production. ECPs from the virulent strain inhibited bead phagocytosis and ROS production. The virulent strain was rapidly internalized in hemocytes.

Keywords: innate immunity, molluscs, cell-mediated immune response, bacterial infections, green fluorescent protein 


\section{Introduction}

Shellfish farms have been impacted by bacterial infectious diseases for many years, inducing repeated episodes of mortality and consequently important economic loss. The most common causative agent is represented by members of the genus Vibrio capable of infecting oysters, abalone, clams, and scallops at different life stages: larval, juvenile and adult (BeazHidalgo et al., 2010a; Travers et al., 2015). Among bivalve species and until recently, mussels were not massively affected by bacterial pathogens (Gestal et al., 2008; Watermann et al., 2008). This relative resistance has been related to a robust innate immunity able to prevent efficiently bacteria infestation (Balbi et al., 2013; Ciacci et al., 2010; Tanguy et al., 2013). Nevertheless, since 2010, abnormal mortality events were also reported for farmed blue mussels (juveniles and adults) in France (Bechemin et al., 2014; Guichard et al., 2011). During this period, different Vibrio strains were isolated from moribund animals. Primary investigations on recent mortality events suggest that these episodes could be accounted for by multiple reasons, including a combination of particular environmental conditions together with biological factors (Bechemin et al., 2014).

Host-pathogen interactions implicate multiple processes initiated both by the pathogen, as a strategy to survive, and the host in an attempt to eliminate the invader (Gestal et al., 2008). Whilst Vibrio virulence has been frequently associated to secretion of extracellular products (Labreuche et al., 2010, 2006), lesions and infection kinetics remain poorly understood because of the diversity of bacteria and the number of hosts and age classes they can infect (Travers et al., 2015). The study of immune systems may help to understand responses of hosts facing invaders. As other bivalves, mussels are endowed of exclusive innate immune responses carried out by circulating hemocytes and soluble hemolymph factors (Canesi et al., 2002).

Mytilus edulis immunocytes form an heterogeneous cell population. They can be classified into 3 main groups of hemocytes, small semi-granular basophils, agranular hyalinocytes and more complex granulocytes (Le Foll et al., 2010). These cells are involved in various physiological functions but their key role consist in internal defense since they are able to recognize, bind, and phagocytize microbes. Phagocytosis is the primary mechanism for bacterial killing and elimination of foreign particles in these organisms. It can be divided into several stages, including chemotaxis, recognition, adhesion, endocytosis and destruction (Gosling, 2015). Mussel hemocytes are motile, they migrate to infected sites following the 
detection of foreign materials (Donaghy et al., 2009), leading to pathogens recognition and adhesion. Internalization is the key stage of microbicidal activity. During this process, sophisticated cascades of reactions involving multiple molecular partners take place. As a consequence, phagocytes produce free radicals derived from oxygen and nitrogen, highly toxic to the ingested pathogens, and release lysosomal enzymes as well as antimicrobial peptides (Canesi et al., 2002; Mitta et al., 2000).

Nevertheless, the immune response is sometimes insufficient to defeat microbial aggressions. Bacteria can be pathogenic to host, having the ability to cause diseases and death. The degree of pathogenicity corresponds to virulence, a phenotype intimately dependent on host-pathogen interactions (Casadevall and Pirofski, 2009; Steinhaus and Martignoni, 1970). Experimental infections of Mytilus sp. and in vitro studies using hemocytes co-incubated with various Vibrios have generated data describing systemic, cellular and molecular responses of mussels to bacteria (Ciacci et al., 2010, 2009; Costa et al., 2009; Parisi et al., 2008; Tanguy et al., 2013). However, bacterial strains used in these studies, like V. splendidus LGP32 or $V$. aestuarianus 01/132, are pathogens of the pacific oyster Crassostrea gigas with, by contrast, no characterized virulence towards the blue mussel. Thus, it should be considered that, up to now, results reported from bacterial challenges of Mytilus sp. immunity were obtained in a context of low virulence.

In this work, we evaluated the virulence of bacterial isolates in the adult blue mussel by carrying out experimental infections and characterizing hemocyte responses. Experimental infections led to the selection of two isolates affiliated to $V$. splendidus $/ V$. hemicentroti groups: a virulent and an innocuous strain. Corresponding GFP-tagged Vibrio strains were constructed and validated to be used in flow cytometry and fluorescence microscopy. Responses of blue mussel hemocytes exposed to virulent/non virulent Vibrio strains or to their extracellular products during different phases of phagocytosis were examined.

\section{Material and methods}

\subsection{Mussel collection}

Adult mussels, M. edulis with shell length ranging from 4 to $5 \mathrm{~cm}$, were collected on the intertidal rocky shore of Yport $\left(0^{\circ} 18^{\prime} 52^{\prime \prime} \mathrm{E}: 49^{\circ} 44^{\prime} 30^{\prime \prime N}\right.$, France) between December 2013 and December 2015, immediately transported to the laboratory and placed in a temperaturecontrolled $\left(10^{\circ} \mathrm{C}\right)$ aerated Biotop Nano Cube 60 seawater tank (Sera, Heinsberg, Germany), equipped with mechanical and activated biological filtering. The animals were fed with algae (Isochrysis galbana) and maintained in these conditions for at least one week before use. 


\subsection{Bacterial strains}

\subsubsection{Isolation from mussels (Laboratoire National de Référence, LNR, La Tremblade)}

Strains used in this study are described in Error! Reference source not found.. Bacteria were isolated from mussel mortality events reported by professionals (French national surveillance network REPAMO) in 2010 and 2013, or from mussel microflora in absence of mortality in the context of Bivalife European project in 2011 and 2012. Briefly, crushed tissues were homogenized in $100 \mu \mathrm{l}$ of Sterile Artificial Sea Water (SASW : $2.3 \%$ (w/v) NaCl, $20 \mathrm{mM}$ $\mathrm{KCl}, 5 \mathrm{mM} \mathrm{MgSO}_{4}, 2 \mathrm{mM} \mathrm{CaCl}_{2}$ ) with a sterile pellet-pestle (Sigma) for 1 minute on average. Samples diluted 100x and 1000x in SASW were plated on Zobell agar (0.4\% peptone, $0.1 \%$ yeast extract, $0.01 \%$ ferric citrate and $1.5 \%$ agar in SASW, $\mathrm{pH} 7.6$ ) and the predominant bacteria were isolated after $48 \mathrm{~h}$ at $20^{\circ} \mathrm{C}$. Pure cultures of bacterial strains were conserved frozen at $-80^{\circ} \mathrm{C}$ in Zobell broth with glycerol $15 \%$.

\subsubsection{Genetic characterization: $g y r B$ sequencing}

Total DNA from a log-phase culture was extracted from cultured Vibrio by boiling in 100 $\mu 1$ of ultrapure water (Saulnier et al., 2009). The gyrB (gyrase B) gene was amplified using the universal bacterial primer pairs (gyrB274F GAAGTTATCATGACGGTACTTC and gyrB1171R CCTTTACGACGAGTCATTTC) and the methods previously described (Thompson et al., 2005). Amplicons with the expected size were purified using a Microcon PCR filter kit (Millipore). Purified PCR products were mixed (final volume $10 \mu \mathrm{l}$ ) with $0.4 \mu \mathrm{l}$ ABI Prism Big Dye Terminator ready reaction mix (Applied Biosystems ${ }^{\circledR}$ ) and $0.75 \mu \mathrm{M}$ of primer. Cycle sequencing reactions were performed using a Gene Amp PCR System 2700 (Applied Biosystems ${ }^{\circledR}$ ) and following the manufacturer's instructions. Separation of the DNA fragments was carried out in an ABI PRISM 3130 XL Genetic Analyzer (Applied Biosystems).

Sequences were aligned using ClustalW (http://www.ebi.ac.uk/Tools/msa/clustalw2/) and BioEdit software (http://www.mbio.ncsu.edu/bioedit/bioedit.html.) Phylogenetic tree was built using Mega6 (http://www.megasoftware.net/mega6/mega.html.). The tree was drawn using the Neighbor-Joining method with the Kimura two-parameter model (Saitou and Nei, 1987). Reliability of topologies was assessed by the bootstrap method (Felsenstein, 1985) with 1000 replicates. The Genbank accession numbers gene sequences obtained in this study or already published in GenBank are presented in Error! Reference source not found. . 


\subsubsection{Characterization of virulence by in vivo injections}

Bacteria were grown overnight in Marine broth or Luria Bertani $\mathrm{NaCl} 20$ g. $\mathrm{L}^{-1}$ at $22^{\circ} \mathrm{C}$ with constant agitation $(80 \mathrm{rpm})$. Cells were washed twice with filtered sterile seawater (FSSW) and centrifuged at $1200 \mathrm{~g}$ for $10 \mathrm{~min}$. The supernatant was discarded and the resulting pellet resuspended in FSSW to obtain an $\mathrm{OD}_{600 \mathrm{~nm}}$ of 1. Mussels were anesthetized for $2-3 \mathrm{~h}$ at $20^{\circ} \mathrm{C}$ in a magnesium chloride solution $\left(\mathrm{MgCl}_{2}\right.$, Sigma Aldrich) at a final concentration of 50 g.L $\mathrm{L}^{-1}$ (1/4: v/v seawater/freshwater) and under aeration. Subsequently, a volume of $100 \mu \mathrm{l}$ of bacterial suspension was injected into the posterior adductor muscle. A group of mussel was injected with FSSW to serve as negative controls. After injection, the animals were transferred to tanks ( 3 replicate tanks, 10 mussels per tank) filled with $2 \mathrm{~L}$ of UV-treated and filtered seawater supplemented with $50 \mathrm{ml}$ of phytoplankton and maintained under static conditions at $20^{\circ} \mathrm{C}$ with aeration. Mortality was monitored each day over a four day period. Animals were considered to be dead when the valves did not close following stimulation. Newly dead mussels were removed from the tanks.

\subsubsection{GFP-tagging by triparental mating}

The pVSV102 plasmid (Dunn et al., 2006) carrying GFP/ kanamycin-resistance expression cassette was transferred from E. coli to Vibrio strains (10/068 1T1, 12/056 M24T1) by triparental mating (Stabb and Ruby, 2002) using the conjugative helper strain CC118 $\lambda$ pir as described by Dunn et al. (2006). Donor, helper and receptor cells were grown overnight to the stationary phase in Luria Bertani (LB) (E. coli strains) and LBS [LB complemented with salt, $\mathrm{NaCl} 20$ g.L $\mathrm{L}^{-1}$ (f.c.), for Vibrio strains] with addition of $40 \mu \mathrm{g} . \mathrm{mL}^{-1}$ kanamycin for DH5 $\alpha$ pVSV102. $100 \mu \mathrm{L}$ of each culture was combined in a microfuge tube, washed in LBS without antibiotics and centrifuged at $1200 \mathrm{~g}$ for $10 \mathrm{~min}$. The resulting pellet was suspended into 10 $\mu \mathrm{L}$ of LBS and dropped on a fresh LBS agar plate and then incubated for 16 hours at $28^{\circ} \mathrm{C}$. The bacterial spot was suspended in $800 \mu \mathrm{L}$ of LBS, serially diluted, plated on LBS plates containing $100 \mu \mathrm{g} . \mathrm{L}^{-1}$ kanamycin and incubated at $18^{\circ} \mathrm{C}$. Donor bacteria were counterselected by growing at $18^{\circ} \mathrm{C}$, whereas the helper strain and the acceptor strain, which did not receive conjugative, plasmids were killed by the antibiotic selection. Therefore, clones were isolated by inoculation into new LBS antibiotic plates and green fluorescent were verified by epifluorescence microscopy. 


\subsubsection{Validation of GFP-tagged strains}

GFP expression conservation: To ensure plasmid conservation, fluorescent bacteria strains were grown overnight in LBS $100 \mu \mathrm{g} . \mathrm{L}^{-1}$ kanamycin at $22^{\circ} \mathrm{C}$. This culture was diluted in LBS without antibiotics and grown at $22^{\circ} \mathrm{C}$ overnight. Every day, a new culture was started with an aliquot of the previous day's culture, which was analyzed by flow cytometry, after dilution.

Growth curves: Parental bacterial strains and GFP-tagged strains were cultivated in LBS at $22^{\circ} \mathrm{C}$ with constant shaking at $80 \mathrm{rpm}$. At regular intervals, the bacterial concentrations in the cultures were evaluated spectrophotometrically at an optical density (OD) of $600 \mathrm{~nm}$.

In vivo injection: To compare virulence between parental and derivative fluorescent strains, GFP-tagged strains were injected intramuscularly into mussels according to the protocol described above for parental strains.

\subsection{Contact with hemocytes}

\subsubsection{Haemolymph collection}

Haemolymph was withdrawn from the posterior adductor muscle sinus, by gentle aspiration with a $1 \mathrm{~mL}$ syringe equipped with a $22 \mathrm{G}$ needle. Quality of samples was systematically checked by microscopic observation before using in bioassays.

\subsubsection{Preparation of bacteria and their extracellular products}

For in vitro experiments, two Vibrio strains were used: 10/068 1T1 and 12/056 M24T1 (parental or GFP-tagged). Bacteria were cultivated overnight in Marine broth or Luria Bertani $\mathrm{NaCl} 20 \mathrm{~g} . \mathrm{L}^{-1}$ at $22^{\circ} \mathrm{C}$, centrifuged at $3000 \mathrm{~g}$ for $10 \mathrm{~min}$. Supernatants were filtered $(0.22 \mu \mathrm{m})$ and conserved at $-20^{\circ} \mathrm{C}$ until use and bacteria were diluted in sterile physiological water $\left(\mathrm{NaCl} 9 \mathrm{~g} . \mathrm{L}^{-1}\right)$ at $10^{8} \mathrm{cfu} . \mathrm{ml}^{-1}$ for immediate utilization.

\subsubsection{Motility}

Hemocyte motility was assessed via live-cell nuclei tracking. The protocol was adapted from Rioult et al. (2013). Briefly cells exposed to bacteria $\left(10^{8} \mathrm{cfu}^{\left.\mathrm{m} \mathrm{m}^{-1}\right)}\right.$ or in marine physiological saline solution (MPSS) pH 7.8, $0.2 \mu \mathrm{m}$ filtered (Rioult et al., 2014) for the control were incubated with $5 \mu \mathrm{M}$ of the nuclei-specific fluorescent probe Hoechst 33342 for 15 minutes at $15^{\circ} \mathrm{C}$. A culture dish was placed on the stage of a TE-2000 inverted microscope (Nikon, Champigny-sur-Marne, France) equipped for epifluorescence excitation (HBO arc lamp with 377/50 $\mathrm{nm}$ bandpath filter) and time-lapse imaging. A Peltier temperature controller (PDMI-2 and TC-202A; Harvard Apparatus, Holliston, MA) keeps preparation at 
$15^{\circ} \mathrm{C}$ for extended live cell imaging. Wild-field epifluorescence time-lapse imaging was performed with a x10 objective (numerical aperture 0,3). A VCM-D1 shutter (Uniblitz, Vincent Associates, NY) was added in the illumination pathway to cut off the excitation light between two image recordings. Camera and shutter were controlled by Metamorph (Molecular Device, Sunnyvale, CA) as acquisition software. A CCD Coolsnap EZ camera (Photometrics, Tucson, AZ) captured 12-bit digital of $1392 \times 1040$ pixels greyscale images every $30 \mathrm{~s}$ for 2 hours (409 $\mathrm{nm}$ long path emission filter). Camera and software were calibrated to express distance in microns. Time-series image stacks were imported into Metamorph Analysis software. The track Objects application (available with MultiDimensional Motion Analysis option) was started. Typically, for each biological replicate, 20 nuclei were randomly chosen to be tracked. Extracted data were transferred to a spreadsheet and, for each cell, the mean distance travelled during 30 seconds was calculated and multiplied by 2 to express velocity in $\mu \mathrm{m} \cdot \mathrm{min}^{-1}$.

\subsubsection{Phagocytosis assay}

The phagocytic ability of hemocytes was determined by flow cytometry using fluorescent beads or GFP tagged bacteria. Internalization of beads or bacteria was verified by microscopic observation.

The protocol was adapted from Costa et al. (2009) with some modifications. Briefly, fluospheres (Fluosphere Carboxylate-Modified Microspheres, $2.00 \mu \mathrm{m}$, yellow-Green, Life technologies) were added to haemolymph to generate minimally a 10:1 bead to hemocyte ratio and cells were incubated for 2,4 and 6 hours at $15^{\circ} \mathrm{C}$ in the dark. The effect of bacterial extracellular products (ECPs) was tested by mixing $100 \mu 1$ of ECPs to cell suspension one hour before adding beads. After incubation, supernatants were gently aspirated and attached cells were removed by adding cold Alsever's solution (300 mM NaCl, 100 mM Glucose, 30 mM sodium Citrate, 26 mM citric acid, 10 mM EDTA, pH 5.4) and analyzed by Beckman Coulter flow cytometer. Phagocytosis was defined as cell internalization of 3 beads or more.

The capacity to phagocyte bacteria was also evaluated. Cells were exposed to GFP-tagged Vibrio strains at 10:1 ratio (bacteria:cell) for 2,4 and 6 hours at $15^{\circ} \mathrm{C}$ in the dark. Before analysis on flow cytometry, propidium iodide was added to quantify the percentage of viable cells.

\subsubsection{ROS production}


Crude haemolymph was placed into individual wells of 24-well tissue-culture plates (Greiner) and cells allowed to adhere for 15 minutes at $15^{\circ} \mathrm{C}$. The haemolymph was removed and replaced with $400 \mu \mathrm{l}$ MPSS $(0.2 \mu \mathrm{m}$ filtered) alone for the control or containing $0.2 \mu \mathrm{M}$ phorbol 12-mystriate 13-acetate (PMA, Sigma) or $100 \mu 1$ of ECPs or heat killed bacteria (15 min at $100^{\circ} \mathrm{C}$ ). For Vibrio challenges, $400 \mu \mathrm{l}$ of bacterial suspension diluted in physiological water at $10^{8} \mathrm{cfu}_{\mathrm{ml}}^{-1}$ were added to hemocytes. After two hours of incubation at $15^{\circ} \mathrm{C}, \mathrm{CM}-$ $\mathrm{H}_{2}$ DCFDA at $0.2 \mu \mathrm{M}$ f.c. was added in each well and plates were incubated 30 minutes at $15^{\circ} \mathrm{C}$ in the dark. Fluorescence was analyzed on flow cytometer (Beckman Coulter).

\subsection{Statistical analyses}

Statistical analysis was performed by using SigmaPlot 12 (Systat Software Inc., Chicago, IL). Replicates were averaged and the values were tested for normality (Shapiro-Wilk) and paired comparisons were performed by Student's t-tests or by Mann-Whitney rank sum tests in case of unequal variance. Statistical significance was accepted for $* p<0.05, * * p<0.01$ or $* * * p<0.001$

\section{Results}

\subsection{Bacteria pathogenicity and genetic characterization}

Bacterial strains were isolated from M. edulis during mortalities events reported by professionals or from mussel microflora in absence of mortalities (Error! Reference source not found.). Fifteen strains of Vibrio isolates were tested at $\mathrm{OD}_{600}=1$ for their pathogenicity toward mussels by experimental infection (Figure 1). First mortalities appears 24 hours postinjection and were comprised between $0 \%$ and $76,6 \%$ indicating different degrees of virulence between bacteria. The most virulent strain was 10/068 1T1 and caused respectively $76,6 \pm 8 \%$ and $90 \pm 5 \%(n=3)$ mortalities after 24 and 96 hours. For 10/060 2T1 and 12/040 $11 \mathrm{~T} 2$ mortalities increased progressively from 5-10\% after $24 \mathrm{~h}$ to $40-47,5 \%$ after 96 hours. Strains 10/058 2T1, 10/058 3T1, 11/100 M22T3, 11/148 M6T2, 12/037 M22T1, 12/037 M24T1, 12/037 M7T1, 12/037 M23T1, 12/056 M1T1, 12/056 M24T1, 13/026 2T3, 13/026 $5 \mathrm{~T} 3$ can be considered as innocuous (mortalities between 0 and $6,6 \%$ after $24 \mathrm{~h}$ ). It is important to notice that some of these strains can induce limited mortalities after 96 hours.

To confirm the virulence of 10/068 1T1 strain, different $\mathrm{OD}_{600}$ doses were injected to mussels (Figure 2). After 24 hours, a dose-dependent mortalities was observed (36,6 $\pm 12 \%$, $\mathrm{n}=3$ mortalities at $\left.\mathrm{OD}_{600}=0.1\right)$. 
Phylogenetic analyses of bacteria isolates based on the housekeeping gene $g y r B$ revealed that the majority of isolated strains belongs to V. Splendidus group and can be affiliated to the $V$. splendidus / V. hemicentroti species, or V. lentus / V. atlanticus species (Figure 3). No clear correlation between phylogeny and virulence can be noticed. Conversely, few virulent strains (3) were identified, all isolated from mussel mortality events (2010 and 2012), and phylogenetically close to non virulent strains isolated from normal flora.

\subsection{Validation of GFP-tagged strains}

Two Vibrio strains were GFP-tagged, the virulent 10/068 1 T1 and the non virulent 12/056 M24T1. To validate their use as genuine models for M. edulis, the fluorescence stability and potential effects of the GFP-plasmid on bacteria growth capacities and virulence were analyzed. Plasmid stability tests, determining the proportion of plasmid-bearing cells remaining overtime, were conducted by culturing the GFP-labeled strains in the absence of antibiotic selection. Both strains 10/068 1T1 and 12/056 M24T1 showed a high stability of GFP encoding plasmid after 14 passages in a non-selective culture (Figure 4a). Bacterial physiology and phenotype after GFP-tagging were also studied. No obvious difference was noticed in growth characteristics (Figure 4b) and colony size or aspect when plated on LBS (not shown). Furthermore, bacteria virulence did not change after transformation, both parental and GFP-tagged 10/068 1T1 strains leading to 90\% mussel mortality in 4 days while parental and labeled 12/056 M24T1 strains caused in this experiment respectively $20 \%$ and $23 \%$ mortalities (Figure 4c).

\subsection{Hemocyte motility}

Hemocyte migration was followed in vitro by nuclei tracking during $2 \mathrm{~h}$ with a recording rate of 1 image/30 sec. Off-line tracking was carried out on a set of 20 nuclei selected randomly in the microscopic field. In control conditions, velocity was stable with values of about $1 \mu \mathrm{m} / \mathrm{min}$. In the presence of $V$. splendidus-related 10/068 1T1 in the imaging chamber, cell velocities were higher, $3.3 \mu \mathrm{m} / \mathrm{min}$ at the beginning of the recording, and increased after $30 \mathrm{~min}$ to reach $4,8 \mu \mathrm{m} / \mathrm{min}$. Then, migration speed decreased and get closer to control velocity after 2 hours of recording. In contrast, the motility of hemocytes exposed to the innocuous strain 12/056 M24T1 increased progressively and exceeded $5 \mu \mathrm{m} / \mathrm{min}$ at the end of the recording (Figure 5a). Standard error of the mean (SEM) values followed the same distribution than mean velocity (Figure 5b). These results indicate that hemocytes coincubated with $V$. splendidus-related 10/068 1T1 had transiently elevated velocities at the 
beginning of the experiments and rapidly converged towards a reduced motility in a bellshaped time course. Conversely, 12/056 M24T1 continuously activated hemocyte speed during motility recordings and provoked a dispersion of single-cell velocities.

\subsection{Phagocytosis assays}

The ability of hemocytes to engulf latex beads was investigated at different time intervals (Figure 6); the percentage of cells containing 3 or more beads increased with incubation time and ranged from $40 \%$ at $2 \mathrm{~h}$ to $56 \%$ at $6 \mathrm{~h}$. The preincubation with 10/068 1T1 ECPs altered significantly the phagocytic capacity at $2 \mathrm{~h}$ with a decrease from $40 \%$ to $22 \%$ and also at $4 \mathrm{~h}$ and 6h (p<0.05). 12/056 M24 T1 ECPs did not affect phagocytosis by comparison to control. The phagocytic capacity of bacteria was evaluated by challenging hemocytes with virulent and non-virulent strains at different exposure time (Figure 7). The percentage of cells containing one bacterium was significantly higher for hemocytes exposed to 12/056 M24T1 than 10/068 1T1, and rates decreased at $6 \mathrm{~h}$. However, cells engulfed 2 bacteria and more were significantly less important for 12/056 M24T1 than 10/068 1T1 and an increase was observed after $6 \mathrm{~h}$ exposure. Furthermore, during phagocytosis hemocytes were viable at $95 \%$ for both strains (data not shown).

\subsection{ROS production}

The capacity of $M$. edulis hemocytes to produce reactive oxygen species was investigated by in vitro exposure to a chemical activator used as a positive control (phorbol 12-mystriate 13-acetate, PMA) and bacterial strains (living or heat killed) or their extracellular products (ECPs) (Figure 8). Immunocytes respond actively and significantly to all treatments. PMA activated a respiratory burst at very low concentration $(0.2 \mu \mathrm{M})$, demonstrating that mussel hemocytes are able to produce toxic radicals. Bacterial strains or corresponding ECPs also induced ROS production. However, significant differences were obtained according to experimental conditions. Hemocyte exposure to non virulent Vibrio (12/056 M24T1) or to 12/056 M24T1 ECPs activated ROS production at levels similar or higher than PMA, respectively. Conversely, when exposed to the strain 10/068 1T1 or its ECPs, hemocytes generated oxygen radicals at amounts significantly inhibited by comparison to PMAstimulated levels without any reduction of cell viability (data not shown). Heat-killed 10/068 $1 \mathrm{~T} 1$ did not significantly modify the response compared to PMA.

\section{Discussion}


Unlike other bivalve species, Mytilus edulis is not known to be particularly affected by any major bacterial disease (Beaz-Hidalgo et al., 2010a; Travers et al., 2015; Watermann et al., 2008). It has been suggested that mussel resistance to bacterial infection was due to the presence of potent immune defense mechanisms (Balbi et al., 2013; Ciacci et al., 2010, 2009; Tanguy et al., 2013). However, while many studies explored mussel immune responses towards Gram + and Gram - bacteria including Vibrios (Costa et al., 2009; Parisi et al., 2008), strain virulence for Mytilus sp. per se was never tested. This lack of data is all the more regrettable that, since 2010, abnormal mortality events have touched farmed blue mussels (juveniles and adults) in France, where different bacterial strains were isolated (Guichard et al., 2011).

In this context, we performed 1) for a first time, an evaluation of virulence and a genetic characterization of bacterial strains isolated from Mytilus edulis, 2) a construction and validation of two stable GFP-tagged $V$. splendidus-related strains for their use in flow cytometry, and 3) a description of functional activity of mussel hemocytes challenged by virulent and non virulent bacteria or by their extracellular products.

\subsection{Pathogenicity of $V$. splendidus-related strains towards the blue mussel}

To evaluate virulence of isolates, experimental infection assays were carried out by injecting bacteria into mussels, intramuscularly. Among the tested strains, 10/068 1T1 showed a high and dose dependent degree of virulence (76.6\% and 90\% mortalities after $24 \mathrm{~h}$ and $96 \mathrm{~h}$ ) whereas 12/056 M24T1 was found innocuous. Phylogenetic analysis using gyrB, one of the more polymorphic housekeeping genes used for $V$. Splendidus clade (Le Roux et al., 2004), revealed the affiliation of both virulent and non virulent bacteria 10/068 1T1 and 12/056 M24T1 to the $V$. splendidus and $V$. hemicentroti type strains. Even if more realistic protocols as immersion or cohabitation challenges are needed to confirm the pathogenic potential of this strain, our injection protocol yet allows a marked differentiation of phylogenetically close strains with contrasted pathotypes ( $76.6 \%$ of mortality induced in 24 hours vs $0 \%$ ).

Different strains related to the Vibrio Splendidus clade were implicated in mortalities of various bivalves, including the pacific oyster (Gay et al., 2004; Lacoste et al., 2001; Saulnier et al., 2010), the atlantic scallop (Lambert et al., 1999; Nicolas et al., 1996), the carpet shell clam (Beaz-Hidalgo et al., 2010b) and the greenshell mussel (Kesarcodi-Watson et al., 2009). An epidemiological study of V. splendidus strains associated with Crassostrea gigas mortalities demonstrated genetic diversity within this group and suggested its polyphyletic 
nature (Le Roux et al., 2004). In fact, the $V$. Splendidus group includes 16 species, many of them containing virulent and non virulent strains (for instance V. celticus, V. crassostreae, $V$. cyclitrophicus, V. tasmaniensis and V. splendidus) (Travers et al., 2015). Concerning $M$. edulis, we conclude that, as in other mollusk species affected by V. splendidus-related strains, a virulent pathotype cannot be discriminated through housekeeping gene sequencing since virulent strains appear phylogenetically close to innocuous ones. To define this pathotype, further studies based on a large collection of strains including ecological populations (Hunt et al., 2008) are needed.

A recent study on normal microflora, i.e. microflora of healthy animals, associated with $M$. galloprovincialis reveals a high diversity of strains belonging to 5 major $V$. splendidus groups (Kwan and Bolch, 2015). In accordance with these results, the majority of analyzed strains are close to $V$. splendidus, $V$. tasmaniensis, $V$. lentus or $V$. atlanticus, even if we didn't find $V$. toranzoniae-affiliated genotypes. Efforts to distinguish $V$. Splendidus-related innocuous bacteria that compose natural microflora of mussel from virulent pathotypes are now necessary.

\subsection{Construction and validation of GFP-tagged bacteria}

To facilitate the study of interactions between $V$. splendidus-related strains and mussel hemocytes, bacteria were tagged with the Green Fluorescent Protein. Fluorescent 10/068 1T1 and 12/056 M24T1 strains showed a high plasmid stability. They constitute useful tools for flow cytometry and epifluorescence microscopy. However, in some cases, the addition of the marker gene generated changes in bacterial physiology or behavior (Aboubaker et al., 2013; Allison and Sattenstall, 2007; Knodler et al., 2005). To investigate undesired virulenceinterfering effects of GFP expression, parental and genetic-engineered bacteria were compared. For both strains, our results indicate that GFP-labeling disturbed neither growth characteristics nor degrees of virulence of bacteria, thus validating the use of 10/068 1T1 and 12/056 M24T1 GFP expressing strains as genuine models for challenging Mytilus edulis.

\subsection{Mytilus hemocyte responses to Vibrio strains}

Hemocytes form the first defense line of the immune system in bivalves. Similarly to cells of the vertebrate monocyte/macrophage lineage, activated hemocytes achieve pathogen elimination through chemotaxis, phagocytosis and cytotoxic processes, essentially (Liu, 2008). 
In an early phase of response to microbial threat, hemocytes migrate toward infected sites. Herein, we explored the influence of V. splendidus-related strains on the motility of Mytilus edulis hemocytes, by using the nuclei tracking method (Rioult et al., 2013). In the absence of stimulation, hemocyte velocity was stable $(1 \mu \mathrm{m} / \mathrm{min})$. In the presence of the innocuous strain 12/056 M24T1, we observe a progressive speed up of cell motility over 2 hours recordings that probably corresponds to a chemoactivation. Chemotactic and chemokinetic responses increase the probability of physical contact between hemocytes and invaders (Schneeweiss and Renwrantz, 1993), accelerating their detection and recognition. In our experiments however, hemocyte exposure to virulent bacteria 10/068 1T1 triggered more complex responses. The first phase lasting 30 min consists in an immediate acceleration in cell migration $(4,7 \mu \mathrm{m} / \mathrm{min})$. Thereafter, hemocyte instantaneous velocity progressively decreased to reach control values after $2 \mathrm{~h}$. This deceleration may be a consequence of bacteria virulence capable to alter cell migration. Only few studies evoked the mobility of bivalve hemocytes, their high clumping potential and chemotactic activity towards pathogens or their extracellular products (Canesi et al., 2002; Pruzzo et al., 2005; Rioult et al., 2013). In blue mussels, Boyden chamber assays revealed that ability of blood cells to generate both chemotactic and chemokinetic reactions depends on the nature of bacteria secreted molecules (Schneeweiss and Renwrantz, 1993). Short-term (40 min) chemoactivation have been reported from oyster hemocytes that migrate to accumulate around bacteria (Alvarez et al., 1995).

After migration, vertebrate as invertebrate phagocytes, on encounter with foreign objects surfaces, respond by sending out finger-like pseudopods to engulf detected particles (Bayne, 1990). This process requires a major reorganization of cytoskeletal elements in the region of the cell where phagocytosis has been triggered (Russell, 2001) and the resulting filaments must be removed from the base of the forming phagosome to enable its closure (Sarantis and Grinstein, 2012). In our study, we first explored the effect of 10/068 1T1 ECPs on M. edulis hemocyte capacity to engulf latex beads.

After 2-hours incubations, results indicate a reduction of phagocytic activity to $22 \%$, instead of $40 \%$ in control conditions, demonstrating the phagocytosis-inhibition ability of secreted products. A similar significant trend was obtained at 4-6h after contact while 12/056 M24T1 ECPs had no effect on phagocytosis. The decrease of phagocytosis may be a consequence of a loss of pseudopodia and reduction of adhesion capacity. This is reminiscent of cell detachments and unspreadings frequently described for bivalve hemocytes challenged with pathogenic Vibrio strains or with their extracellular products. For example, adhesion and phagocytic activity of pacific oyster hemocytes were altered in contact with $V$. aestuarianus 
01/32 ECPs or V. tubiashii 07/118 T2 ECPs (Labreuche et al., 2006; Mersni-Achour et al., 2014) in a manner that was dependent on ECPs doses (Labreuche et al., 2006). The same hemocyte responses were reported for Mytilus edulis and Mya arenaria hemocytes challenged with the oyster pathogen V. splendidus LGP32 (Araya et al., 2009; Tanguy et al., 2013). Nevertheless, precise molecular mechanisms involved in bacteria alteration of hemocyte phagocytosis are still unclear. Involvement of metalloprotease activities have been suggested since such enzymes are present in ECPs of virulent Vibrios and since the metalloenzyme Vsm, secreted by V. splendidus LGP32 is toxic to oysters (Binesse et al., 2008). So, it will be interesting to explore the effect of 10/068 1T1 ECPs on adult mussel.

Direct hemocyte phagocytosis of virulent and non virulent GFP-tagged bacteria was also quantitatively investigated. The number of hemocytes strictly containing one engulfed Vibrio decreased with time. This number was lower for cells exposed to the virulent strain 10/068 $1 \mathrm{~T} 1$ than for hemocytes incubated with the innocuous strain 12/056 M24T1. In appearance, this result may suggest a more efficient destruction of Vibrio 10/068 1T1. Interestingly however, analysis of hemocytes containing 2 or more Vibrios results in opposite findings. The percentage hemocytes with 2 or more engulfed bacteria increased time-dependently but was higher for the virulent strain. This latest observation is rather consistent with a faster internalization of the pathogenic 10/068 1T1 strain in hemocytes, compared to 12/056 M24T1.

In some extent, internalization by host cells may be advantageous for invaders to effectively establish infection and to colonize tissues (Sarantis and Grinstein, 2012). Such mechanisms were observed in some Vibrio species, usually considered as extracellular pathogens but having obviously intracellular stages (Duperthuy et al., 2011). This is especially the case of, the coral pathogen $V$. shiloii which invades epithelial cells (Banin et al., 2000) and of $V$. splendidus LGP32, able to attach and invade oyster hemocytes through OmpU porin (Duperthuy et al., 2011). In a good agreement with these studies, it can be proposed that the virulent strain 10/068 1T1 invades mussel hemocytes actively, although its interaction with the cell inner environment remain to be determined.

Among the events taking place during the immune response, the oxidative burst plays an important role in microbe destruction. ROS are lethal weapons used by phagocytes to kill microbial invaders, directly, by causing oxidative damage to biocompounds, or indirectly, by stimulating pathogen elimination (Paiva and Bozza, 2014). In Mytilus edulis, we confirmed the capacity of hemocyte to produce oxygen radicals after stimulation by PMA at low doses (García-García et al., 2008). When exposed to non virulent bacteria, mussel blood cells also 
produced ROS at levels equivalent to the PMA treated group, 12/056 M24T1 ECPs also enhanced oxidative bursts. Increases of ROS production by hemocytes exposed to bacteria or to their extracellular products have been previously reported in the blue mussel (Tanguy et al., 2013) and other bivalves species (Buggé et al., 2007; Lambert et al., 2003).

In the presence of virulent bacteria or of their ECPs, but not after hemocyte exposure to heat killed virulent bacteria, ROS production was significantly inhibited by comparison to PMA-stimulated levels. These data reveal the capacity of the pathogenic $V$. splendidus-related strain 10/068 1T1 to alter cell activation by itself but also through secreted products. As a consequence, it is possible that the pathogenic bacterial strain 10/068 1T1 actually quenches ROS production in M. edulis hemocytes as a mean to survive within host cells. In this respect, a wide variety of microbes have developed strategies to promote their survival within hostile cellular environment, in particular by inhibition of ROS-mediated host responses (Spooner and Yilmaz, 2011). For example Densmore et al. (1998) have demonstrated an inhibition of oxidative burst in trout phagocytes, previously stimulated by PMA in the presence of $R$. salmoninarum ECPs. In invertebrates, L. anguillarum does not induce any oxidative burst in Crassostrea virginica hemocytes (Bramble and Anderson, 1997) and quenches ROS production in lobster hemocytes (Moss and Allam, 2006). Likewise, the pathogenic strain $V$. harveyi does not elicit ROS production when added to shrimp hemocytes contrary to a probiotic strain of $V$. alginolyticus which induces cell activation (Muñoz et al., 2000). In addition, $V$. splendidus LGP32 exhibits intracellular survival capabilities and escape from host cellular defenses by avoiding acidic vacuole formation and by limiting ROS production (Duperthuy et al., 2011).

\section{Conclusion}

In this study, we selected two V. splendidus-related strains and constructed GFP-tagged models. The 10/068 1T1 strain was isolated from mortality events reported by professionals and proven as virulent to blue mussel. The 12/056 M24T1 strain was isolated from normal flora and found as innocuous. Functional immune responses of hemocytes challenged by different strains were explored through cell motility, phagocytosis and oxidative burst. Virulent bacteria generated stronger immunocyte responses. Overall, 10/068 1T1 enhanced instantaneously cell migration but adversely affected cell motility after 2 hours exposures. These bacteria were also able to quench ROS production and to alter phagocytosis capacity through ECPs secretion. It has been shown that virulent bacteria were rapidly internalized by hemocytes, suggesting more the involvement of a pathogen-controlled invasion strategy than 
505

506

507

508

509

510

511

512

513

514

515

516

517

518

519

520

521

522

523

524

525

526

527

528

529

530

531

532

533

534

an immune cell-driven phagocytosis process. Taken together, our data support the hypothesis that some bivalve pathogens escape cellular immune response by dysregulation of some hemocyte bactericidal activities. Further investigations are necessary to establish whether hemocytes also constitute carriers for tissues infection.

\section{Acknowledgements}

This work received fundings from the State/Region Plan Contract (CPER) allocated through the Research Federation FED 4116 SCALE (Sciences Appliquées à L'Environnement), ), from the FP7-European project BIVALIFE 'Controlling infectious diseases in oysters and mussels in Europe' (Grant Agreement 266157) and DGAl support through National Reference Laboratory activities for mollusk diseases (Ifremer-La Tremblade). Yosra Ben Cheikh was a recipient for a Ph.D. grant from the Conseil Regional de Haute-Normandie. The authors are indebted to the marine fish farm Aquacaux (Octeville, France) for valuable technical assistance. Dr. Eric Stabb (Dept. Microbiology, University of Georgia, Athens, USA) is kindly acknowledged for providing us with his excellent Vibrio vectors and helper strain. We also thanks LGPMM technical unit, Manon Garrigues and Philippe Haffner for their contribution.

\section{Supplementary data}

Video 1: Epifluorescence time-lapse microscopy of hemocytes plated in a culture dish and coincubated at $15^{\circ} \mathrm{C}$ with the $10 / 0681 \mathrm{~T} 1$ Vibrio strain. Nuclei were stained with a vital DNA dye Hoechst $33342(5 \mu \mathrm{M})$. Recording time, 2 hours. Imaging interval time, $30 \mathrm{sec}$.

\section{References}

Aboubaker, M.H., Sabrié, J., Huet, M., Koken, M., 2013. Establishment of stable GFP-tagged Vibrio aestuarianus strains for the analysis of bacterial infection-dynamics in the Pacific oyster, Crassostrea gigas. Vet. Microbiol. 164, 392-398.

Allison, D.G., Sattenstall, M.A., 2007. The influence of green fluorescent protein incorporation on bacterial physiology: a note of caution. J. Appl. Microbiol. 103, 318-324.

Alvarez, M.R., Friedl, F.E., Roman, F.R., 1995. In vivo chemoactivation of oyster hemocytes induced by bacterial secretion products. J. Invertebr. Pathol. 66, 287-292. 
Araya, M.T., Siah, A., Mateo, D.R., Markham, F., McKenna, P., Johnson, G.R., Berthe, F.C.J., 2009. Morphological and molecular effects of Vibrio splendidus on hemocytes of softshell clams, Mya arenaria. Journal of Shellfish Research 28, 751-758.

Balbi, T., Fabbri, R., Cortese, K., Smerilli, A., Ciacci, C., Grande, C., Vezzulli, L., Pruzzo, C., Canesi, L., 2013. Interactions between Mytilus galloprovincialis hemocytes and the bivalve pathogens Vibrio aestuarianus 01/032 and Vibrio splendidus LGP32. Fish Shellfish Immunol. 35, 1906-1915.

Banin, E., Israely, T., Kushmaro, A., Loya, Y., Orr, E., Rosenberg, E., 2000. Penetration of the coral-bleaching bacterium Vibrio shiloi into Oculina patagonica. Appl Environ Microbiol 66, 3031-3036.

Bayne, C.J., 1990. Phagocytosis and non-self recognition in invertebrates phagocytosis appears to be an ancient line of defense. BioScience 40, 723-731.

Beaz-Hidalgo, R., Balboa, S., Romalde, J.L., Figueras, M.J., 2010a. Diversity and pathogenecity of Vibrio species in cultured bivalve molluscs. Environ Microbiol Rep 2, 34 43.

Beaz-Hidalgo, R., Diéguez, A.L., Cleenwerck, I., Balboa, S., Doce, A., de Vos, P., Romalde, J.L., 2010b. Vibrio celticus sp. nov., a new Vibrio species belonging to the Splendidus clade with pathogenic potential for clams. Syst. Appl. Microbiol. 33, 311-315.

Bechemin, C., Soletchnik, P., Polsenaere, P., Le Moine, O., Pernet, F., Protat, M., Fuhrmann, M., Quere, C., Goulitquer, S., Corporeau, C., Renault, T., Lapegue, S., Travers, M.-A., Morga, B., Garriques, M., Garcia, C., Haffner, P., Dubreuil, C., Faury, N., Baillon, L., Baud, J.-P., 2014. Surmortalités de la moule bleue Mytilus edulis dans les Pertuis Charentais (mars 2014).

Binesse, J., Delsert, C., Saulnier, D., Champomier-Vergès, M.-C., Zagorec, M., MunierLehmann, H., Mazel, D., Le Roux, F., 2008. Metalloprotease vsm is the major determinant of toxicity for extracellular products of Vibrio splendidus. Appl. Environ. Microbiol. 74, 71087117.

Bramble, L., Anderson, R.S., 1997. Modulation of Crassostrea virginica hemocyte reactive oxygen species production by Listonella anguillarum. Dev. Comp. Immunol. 21, 337-348.

Buggé, D.M., Hégaret, H., Wikfors, G.H., Allam, B., 2007. Oxidative burst in hard clam (Mercenaria mercenaria) haemocytes. Fish Shellfish Immunol. 23, 188-196.

Canesi, L., Gallo, G., Gavioli, M., Pruzzo, C., 2002. Bacteria-hemocyte interactions and phagocytosis in marine bivalves. Microsc. Res. Tech. 57, 469-476.

Casadevall, A., Pirofski, L.-A., 2009. Virulence factors and their mechanisms of action: the view from a damage-response framework. J Water Health 7 Suppl 1, S2-S18. 
Ciacci, C., Betti, M., Canonico, B., Citterio, B., Roch, P., Canesi, L., 2010. Specificity of antiVibrio immune response through p38 MAPK and PKC activation in the hemocytes of the mussel Mytilus galloprovincialis. J. Invertebr. Pathol. 105, 49-55.

Ciacci, C., Citterio, B., Betti, M., Canonico, B., Roch, P., Canesi, L., 2009. Functional differential immune responses of Mytilus galloprovincialis to bacterial challenge. Comp. Biochem. Physiol. B, Biochem. Mol. Biol. 153, 365-371.

Costa, M.M., Prado-Alvarez, M., Gestal, C., Li, H., Roch, P., Novoa, B., Figueras, A., 2009. Functional and molecular immune response of Mediterranean mussel (Mytilus galloprovincialis) haemocytes against pathogen-associated molecular patterns and bacteria. Fish Shellfish Immunol. 26, 515-523.

Densmore, C.L., Smith, S.A., Holladay, S.D., 1998. In vitro effects of the extracellular protein of Renibacterium salmoninarum on phagocyte function in brook trout (Salvelinus fontinalis). Vet. Immunol. Immunopathol. 62, 349-357.

Donaghy, L., Lambert, C., Choi, K.-S., Soudant, P., 2009. Hemocytes of the carpet shell clam (Ruditapes decussatus) and the Manila clam (Ruditapes philippinarum): Current knowledge and future prospects. Aquaculture 297, 10-24.

Dunn, A.K., Millikan, D.S., Adin, D.M., Bose, J.L., Stabb, E.V., 2006. New rfp- and pES213derived tools for analyzing symbiotic Vibrio fischeri reveal patterns of infection and lux expression in situ. Appl. Environ. Microbiol. 72, 802-810.

Duperthuy, M., Schmitt, P., Garzón, E., Caro, A., Rosa, R.D., Le Roux, F., LautrédouAudouy, N., Got, P., Romestand, B., de Lorgeril, J., Kieffer-Jaquinod, S., Bachère, E., Destoumieux-Garzón, D., 2011. Use of OmpU porins for attachment and invasion of Crassostrea gigas immune cells by the oyster pathogen Vibrio splendidus. Proc. Natl. Acad. Sci. U.S.A. 108, 2993-2998.

Felsenstein, J., 1985. Confidence limits on phylogenies: An approach using the bootstrap. evolution 39, 783-791.

García-García, E., Prado-Alvarez, M., Novoa, B., Figueras, A., Rosales, C., 2008. Immune responses of mussel hemocyte subpopulations are differentially regulated by enzymes of the PI 3-K, PKC, and ERK kinase families. Dev. Comp. Immunol. 32, 637-653.

Gay, M., Renault, T., Pons, A.-M., Le Roux, F., 2004. Two Vibrio splendidus related strains collaborate to kill Crassostrea gigas: taxonomy and host alterations. Dis. Aquat. Org. 62, 6574 .

Gestal, C., Roch, P., Renault, T., Pallavicini, A., Paillard, C., Novoa, B., Oubella, R., Venier, P., Figueras, A., 2008. Study of diseases and the immune system of bivalves using molecular biology and genomics. Reviews in Fisheries Science 16, 133-156.

Gosling, E., 2015. Marine bivalve molluscs. John Wiley \& Sons. 
606

607

608

609

610

611

612

613

614

615

616

617

618

619

620

621

622

623

624

625

626

627

628

629

630

631

632

633

634

635

636

637

638

639

640

641

Guichard, B., Francois, C., Joly, J.-P., Garcia, C., Saulnier, D., Pepin, J.-F., Arzul, I., Omnes, E., Tourbiez, D., Faury, N., Haffner, P., Chollet, B., Robert, M., Renault, T., Rauflet, F., Le Gagneur, E., Ropert, M., Mouillard, G., Gerla, D., Annezo, J.-P., Le Gal, D., Langlade, A., Bedier, E., Brerette, S., Chabirand, J.-M., Grizon, J., Robert, S., Courtois, O., Rumebe, M., Cantin, C., 2011. Bilan 2010 du réseau Repamo - Réseau national de surveillance de la santé des mollusques marins.

Hunt, D.E., David, L.A., Gevers, D., Preheim, S.P., Alm, E.J., Polz, M.F., 2008. Resource partitioning and sympatric differentiation among closely related bacterioplankton. Science 320, 1081-1085.

Kesarcodi-Watson, A., Kaspar, H., Lategan, M.J., Gibson, L., 2009. Two pathogens of Greenshell mussel larvae, Perna canaliculus: Vibrio splendidus and a $V$. coralliilyticus/neptunius-like isolate. J. Fish Dis. 32, 499-507.

Knodler, L.A., Bestor, A., Ma, C., Hansen-Wester, I., Hensel, M., Vallance, B.A., SteeleMortimer, O., 2005. Cloning vectors and fluorescent proteins can significantly inhibit Salmonella enterica virulence in both epithelial cells and macrophages: implications for bacterial pathogenesis studies. Infect. Immun. 73, 7027-7031.

Kwan, T.N., Bolch, C.J.S., 2015. Genetic diversity of culturable Vibrio in an Australian blue mussel Mytilus galloprovincialis hatchery. Dis. Aquat. Org. 116, 37-46.

Labreuche, Y., Le Roux, F., Henry, J., Zatylny, C., Huvet, A., Lambert, C., Soudant, P., Mazel, D., Nicolas, J.-L., 2010. Vibrio aestuarianus zinc metalloprotease causes lethality in the Pacific oyster Crassostrea gigas and impairs the host cellular immune defenses. Fish Shellfish Immunol. 29, 753-758.

Labreuche, Y., Soudant, P., Gonçalves, M., Lambert, C., Nicolas, J.-L., 2006. Effects of extracellular products from the pathogenic Vibrio aestuarianus strain 01/32 on lethality and cellular immune responses of the oyster Crassostrea gigas. Dev. Comp. Immunol. 30, 367379.

Lacoste, A., Jalabert, F., Malham, S., Cueff, A., Gélébart, F., Cordevant, C., Lange, M., Poulet, S.A., 2001. A Vibrio splendidus strain is associated with summer mortality of juvenile oysters Crassostrea gigas in the Bay of Morlaix (North Brittany, France). Dis. Aquat. Org. 46, 139-145.

Lambert, C., Nicolas, J.L., Cilia, V., 1999. Vibrio splendidus-related strain isolated from brown deposit in scallop (pecten maximus) cultured in Brittany (France). Bull. Eur. Ass. Fish Pathol. 102.

Lambert, C., Soudant, P., Choquet, G., Paillard, C., 2003. Measurement of Crassostrea gigas hemocyte oxidative metabolism by flow cytometry and the inhibiting capacity of pathogenic Vibrios. Fish Shellfish Immunol. 15, 225-240. 
Le Foll, F., Rioult, D., Boussa, S., Pasquier, J., Dagher, Z., Leboulenger, F., 2010.

643 Characterisation of Mytilus edulis hemocyte subpopulations by single cell time-lapse motility imaging. Fish Shellfish Immunol. 28, 372-386.

Le Roux, F., Gay, M., Lambert, C., Nicolas, J.L., Gouy, M., Berthe, F., 2004. Phylogenetic study and identification of Vibrio splendidus-related strains based on $\operatorname{gyr} B$ gene sequences. Dis. Aquat. Org. 58, 143-150.

Liu, D.-W., 2008. Opioid peptides and innate immune response in mollusc. Protein Pept. Lett. 15, 683-686.

Mersni-Achour, R., Imbert-Auvray, N., Huet, V., Ben Cheikh, Y., Faury, N., Doghri, I., Rouatbi, S., Bordenave, S., Travers, M.-A., Saulnier, D., Fruitier-Arnaudin, I., 2014. First description of French V. tubiashii strains pathogenic to mollusk: II. Characterization of properties of the proteolytic fraction of extracellular products. J. Invertebr. Pathol. 123, 4959.

Mitta, G., Vandenbulcke, F., Roch, P., 2000. Original involvement of antimicrobial peptides in mussel innate immunity. FEBS Lett. 486, 185-190.

Moss, B., Allam, B., 2006. Fluorometric measurement of oxidative burst in lobster hemocytes and inhibiting effect of pathogenic bacteria and hypoxia. Journal of Shellfish Research 25, 1051-1057.

Muñoz, M., Cedeño, R., Rodríguez, J., van der Knaap, W.P.W., Mialhe, E., Bachère, E., 2000. Measurement of reactive oxygen intermediate production in haemocytes of the penaeid shrimp, Penaeus vannamei. Aquaculture 191, 89-107.

Paiva, C.N., Bozza, M.T., 2014. Are reactive oxygen species always detrimental to pathogens? Antioxid. Redox Signal. 20, 1000-1037.

Parisi, M.-G., Li, H., Jouvet, L.B.P., Dyrynda, E.A., Parrinello, N., Cammarata, M., Roch, P., 2008. Differential involvement of mussel hemocyte sub-populations in the clearance of bacteria. Fish Shellfish Immunol. 25, 834-840.

Pruzzo, C., Gallo, G., Canesi, L., 2005. Persistence of Vibrios in marine bivalves: the role of interactions with haemolymph components. Environ. Microbiol. 7, 761-772.

Rioult, D., Lebel, J.-M., Le Foll, F., 2013. Cell tracking and velocimetric parameters analysis as an approach to assess activity of mussel (Mytilus edulis) hemocytes in vitro. Cytotechnology 65, 749-758.

Rioult, D., Pasquier, J., Boulangé-Lecomte, C., Poret, A., Abbas, I., Marin, M., Minier, C., Le Foll, F., 2014. The multi-xenobiotic resistance (MXR) efflux activity in hemocytes of Mytilus edulis is mediated by an ATP binding cassette transporter of class C (ABCC) principally inducible in eosinophilic granulocytes. Aquat. Toxicol. 153, 98-109.

Russell, D.G., 2001. Phagocytosis, in: eLS. John Wiley \& Sons, Ltd. 
Saitou, N., Nei, M., 1987. The neighbor-joining method: a new method for reconstructing phylogenetic trees. Mol. Biol. Evol. 4, 406-425.

Sarantis, H., Grinstein, S., 2012. Subversion of phagocytosis for pathogen survival. Cell Host Microbe 12, 419-431.

Saulnier, D., De Decker, S., Haffner, P., 2009. Real-time PCR assay for rapid detection and quantification of Vibrio aestuarianus in oyster and seawater: a useful tool for epidemiologic studies. J. Microbiol. Methods 77, 191-197.

Saulnier, D., De Decker, S., Haffner, P., Cobret, L., Robert, M., Garcia, C., 2010. A largescale epidemiological study to identify bacteria pathogenic to Pacific oyster Crassostrea gigas and correlation between virulence and metalloprotease-like activity. Microb. Ecol. 59, 787798.

Schneeweiss, H., Renwrantz, L., 1993. Analysis of the attraction of haemocytes from Mytilus edulis by molecules of bacterial origin. Dev. Comp. Immunol. 17, 377-387.

Nicolas, J.L., Corre, S., Gauthier, G., Robert, R., Ansquer, D., 1996. Bacterial problems associated with scallop Pecten maximus larval culture. Diseases of Aquatic Organisms Disease Aquat Org 27, 67-76.

Spooner, R., Yilmaz, Ö., 2011. The role of Reactive-Oxygen-Species in microbial persistence and inflammation. Int J Mol Sci 12, 334-352.

Stabb, E.V., Ruby, E.G., 2002. RP4-based plasmids for conjugation between Escherichia coli and members of the Vibrionaceae. Meth. Enzymol. 358, 413-426.

Steinhaus, Edward Arthur, Martignoni, Mauro E., 1970. An abridged glossary of terms used in invertebrate pathology

Tanguy, M., McKenna, P., Gauthier-Clerc, S., Pellerin, J., Danger, J.-M., Siah, A., 2013. Functional and molecular responses in Mytilus edulis hemocytes exposed to bacteria, Vibrio splendidus. Dev. Comp. Immunol. 39, 419-429.

Thompson, F.L., Gevers, D., Thompson, C.C., Dawyndt, P., Naser, S., Hoste, B., Munn, C.B., Swings, J., 2005. Phylogeny and molecular identification of Vibrios on the basis of multilocus sequence analysis. Appl. Environ. Microbiol. 71, 5107-5115.

Travers, M.-A., Boettcher Miller, K., Roque, A., Friedman, C.S., 2015. Bacterial diseases in marine bivalves. Journal of Invertebrate Pathology.

Watermann, B.T., Herlyn, M., Daehne, B., Bergmann, S., Meemken, M., Kolodzey, H., 2008. Pathology and mass mortality of Pacific oysters, Crassostrea gigas (Thunberg), in 2005 at the East Frisian coast, Germany. J. Fish Dis. 31, 621-630. 
715

Figure 1. Cumulative mortalities recorded after experimental bacterial infections of adult mussels. Bacterial strains were grown for $24 \mathrm{~h}$ in Marine broth before resuspension into filtered sterile seawater (FSSW) and adjustment to $\mathrm{OD}_{600}=1$. One hundred microliters of bacterial suspension were injected intramuscularly to anesthetized mussels (10 animals/replicate). Mussels injected with FSSW were used as control. Data are means \pm SEM of cumulative mortalities triplicate tanks

Figure 2. Effect of inoculum size on mussel mortality. Dose-response effect of $V$. splendidusrelated strain 10/068 1T1 on adult mussels estimated 24 hours post-injection. Mussels injected with FSSW were used as control. Data are means \pm SEM of triplicate tanks.

Figure 3. Phylogenetic analysis of bacteria strains based on gyrB gene sequencing.

The percentage of replicate trees in which the associated taxa clustered together in the bootstrap test (1000 replicates) are shown next to the branches. The analysis was carried out by the neighbor-joining method on 34 nucleotide sequences and 529 positions in the final dataset. Evolutionary analyses were conducted in MEGA6. Virulence of bacteria, assessed by the percentage of mortality induced 24 hours post-injection is indicated by the horizontal bars.

Figure 4. Plasmid expression stability in Vibrio strains and effect of GFP expression on growth capacities and virulence. (a) Fluorescence conservation in GFP-tagged bacteria over time. Strains were cultivated in non-selective LBS medium and fluorescence was estimated by flow cytometry. (b) Growth curve of parental and GFP-tagged bacteria at $22^{\circ} \mathrm{C}$ in LBS medium ( $n=3 \pm S E M)$. (c) Comparison of virulence capacity of parental and GFP-tagged strains on adult mussels ( $n=3 \pm$ SEM).

Figure 5. Effect of V. splendidus-related strains on hemocyte motility. M. edulis hemocytes were challenged by $V$. splendidus-related strains 10/068 $1 \mathrm{~T} 1$ or $12 / 056 \mathrm{M} 24 \mathrm{~T} 1$ at $10^{8} \mathrm{cfu}_{\mathrm{ml}}{ }^{-1}$ or incubated in MPSS (control) during $2 \mathrm{~h}$ at $15^{\circ} \mathrm{C}$. (a) Mean velocity of 60 nuclei (3 independents experiences) obtained from centroid XY coordinate changes in the microscopic 
field between two successive images, separated by 30 seconds. (b) Standard errors of the mean taken from (a).

Figure 6. Effect of bacterial ECPs on bead phagocytosis ability. (a) Flow cytometry analysis of hemocyte incubated in vitro with latex beads during 2, 4 and 6 hours. The percentage of cells containing 3 beads or more was measured (mean \pm SEM, $n=6, p<0.05$, Student's t-test). (b) Phase contrast $(\mathrm{Ph})$ and fluorescence (Fitc) microscopy observation of hemocytes after 2 hours phagocytosis (bar $10 \mu \mathrm{m})$.

Figure 7. Hemocyte phagocytic ability towards GFP-tagged bacteria. (a) Comparison between the internalization of virulent and non-virulent bacteria after in vitro exposure during 2, 4 and 6 hours. Left $\mathrm{Y}$-axis and solid bars refer to the percentage of hemocytes containing 2 or more bacteria. Right $\mathrm{Y}$-axis and dashed bars refer to the percentage of hemocytes containing at least one Vibrio. Significant values respectively to non-virulent strain are represented with *** ( $\mathrm{p}<0.001$, Student's t-test). Data are means \pm SEM, $\mathrm{n}=6$. (b) Phase contrast $(\mathrm{Ph})$ and fluorescence (Fitc) microscopy observations of hemocyte after internalization of Vibrio strains 10/068 1T1 or 12/056 M24T1, bar $10 \mu \mathrm{m}$.

Figure 8. ROS production in M. edulis hemocytes. Hemocytes were pre-exposed 2 hours to heat killed or living virulent bacteria at $10^{8} \mathrm{cfu}^{\mathrm{m} l^{-1}}$, non-virulent bacterial strain at $10^{8} \mathrm{cfu} \cdot \mathrm{ml}^{-}$ ${ }^{1}$, or their extracellular products or PMA 0,2 $\mu \mathrm{M}$. Cell fluorescence was quantified by flow cytometry after incubation with $\mathrm{CM}-\mathrm{H}_{2} \mathrm{DCFDA}$ at $0.2 \mu \mathrm{M}$ f.c. Data are means of fluorescence \pm SEM, A.U., $\mathrm{n}=6$. * indicates significant differences from control (Mann-Whitney rank sum test, $\mathrm{p}<0.05$ ) and $\S$ marks significant differences from PMA (Student's t-test $\S \mathrm{p}<0.05, \S \S \S$ $\mathrm{p}<0.001$. 
Table 1. Strains used in this study

\begin{tabular}{|c|c|c|c|}
\hline Strain & Isolation from & Context & Date \\
\hline $10 / 0582 \mathrm{~T} 1$ & Mussel, baie de Somme (80) France & Mussel mortality & 2010, May 18 \\
\hline 10/058 3T1 & Mussel, baie de Somme (80) France & Mussel mortality & 2010, May 18 \\
\hline $10 / 0602 \mathrm{~T} 1$ & Mussel, baie d'Authie (62) France & Mussel mortality & 2010, May 19 \\
\hline 10/068 1T1 & Mussel, baie de Camaret (29) France & Mussel mortality & 2010, May 31 \\
\hline 11/100 M22T3 & Mussel, d'Agnas (17) France & Absence of mortality & 2011, June 29 \\
\hline 11/148 M6T2 & Mussel, d'Agnas (17) France & Absence of mortality & 2011, October 11 \\
\hline 12/037 M22T1 & Mussel, d'Agnas (17) France & Absence of mortality & 2012, May 22 \\
\hline 12/037 M23T1 & Mussel, d'Agnas (17) France & Absence of mortality & 2012, May 22 \\
\hline 12/037 M24T1 & Mussel, d'Agnas (17) France & Absence of mortality & 2012, May 22 \\
\hline 12/037 M7T1 & Mussel, d'Agnas (17) France & Absence of mortality & 2012, May 22 \\
\hline $12 / 04011 \mathrm{~T} 2$ & Mussel, Oye Plage (62) France & Mussel mortality & 2012, May 24 \\
\hline 12/056 M1T1 & Mussel, d'Agnas (17) France & Absence of mortality & 2012, June 05 \\
\hline 12/056 M24T1 & Mussel, d'Agnas (17) France & Absence of mortality & 2012, June 05 \\
\hline $13 / 0262 \mathrm{~T} 3$ & Mussel, Oye Plage (62) France & Mussel mortality & 2013, April 08 \\
\hline $13 / 0265 \mathrm{~T} 3$ & Mussel, Oye Plage (62) France & Mussel mortality & 2013, April 08 \\
\hline
\end{tabular}


1 Table 1.Gyrase B gi reference

\begin{tabular}{|c|c|}
\hline gi number & reference strains \\
\hline gi|164456642 & Vibrio brasiliensis strain LMG 20546T \\
\hline gi|164456646 & Vibrio chagasii strain LMG $21353 \mathrm{~T}$ \\
\hline gi|164456648 & Vibrio cholerae strain IID 6019 \\
\hline gi|164456652 & Vibrio crassostreae strain LMG $22240 \mathrm{~T}$ \\
\hline gi|164456656 & Vibrio cyclitrophicus strain LMG 21359T \\
\hline gi|164456666 & Vibrio fortis strain LMG $21557 \mathrm{~T}$ \\
\hline gi|164456672 & Vibrio gigantis strain LMG $22741 \mathrm{~T}$ \\
\hline gi|164456684 & Vibrio kanaloae strain LMG 20539T \\
\hline gi|164456686 & Vibrio lentus strain LMG 21034T \\
\hline gi|164456718 & Vibrio pomeroyi strain LMG $20537 \mathrm{~T}$ \\
\hline gi|164456730 & Vibrio splendidus strain LMG $19031 \mathrm{~T}$ \\
\hline gi|164456734 & Vibrio tasmaniensis strain LMG 20012T \\
\hline gi|164456742 & Vibrio xuii strain LMG 21346T \\
\hline gi|564274123 & Vibrio artabrorum strain CAIM $1845 \mathrm{~T}$ \\
\hline gi|564274125 & Vibrio atlanticus strain CAIM $1847 \mathrm{~T}$ \\
\hline gi|564274131 & Vibrio celticus strain CAIM $1849 \mathrm{~T}$ \\
\hline gi|754496442 & Vibrio gallaecicus strain CECT 7244T \\
\hline gi|564274143 & Vibrio toranzoniae strain CAIM $1869 \mathrm{~T}$ \\
\hline KU145472 & 10/058 2T1 \\
\hline KU145473 & 10/058 3T1 \\
\hline KU145474 & $10 / 0602 \mathrm{~T} 1$ \\
\hline KU145475 & 10/068 1T1 \\
\hline KU145476 & 11/100 M22T3 \\
\hline KU145477 & 11/148 M6T2 \\
\hline KU145478 & 12/037 M22T1 \\
\hline KU145479 & 12/037 M23T1 \\
\hline KU145480 & 12/037 M24T1 \\
\hline
\end{tabular}




\begin{tabular}{|l|l|}
\hline KU145481 & $12 / 037$ M7T1 \\
\hline KU145482 & $12 / 040$ 11T2 \\
\hline KU145483 & $12 / 056$ M1T1 \\
\hline KU145486 & $12 / 056$ M24T1 \\
\hline KU145484 & $13 / 0262 \mathrm{~T} 3$ \\
\hline KU145485 & $13 / 0265 \mathrm{~T} 3$ \\
\hline
\end{tabular}

2

3 


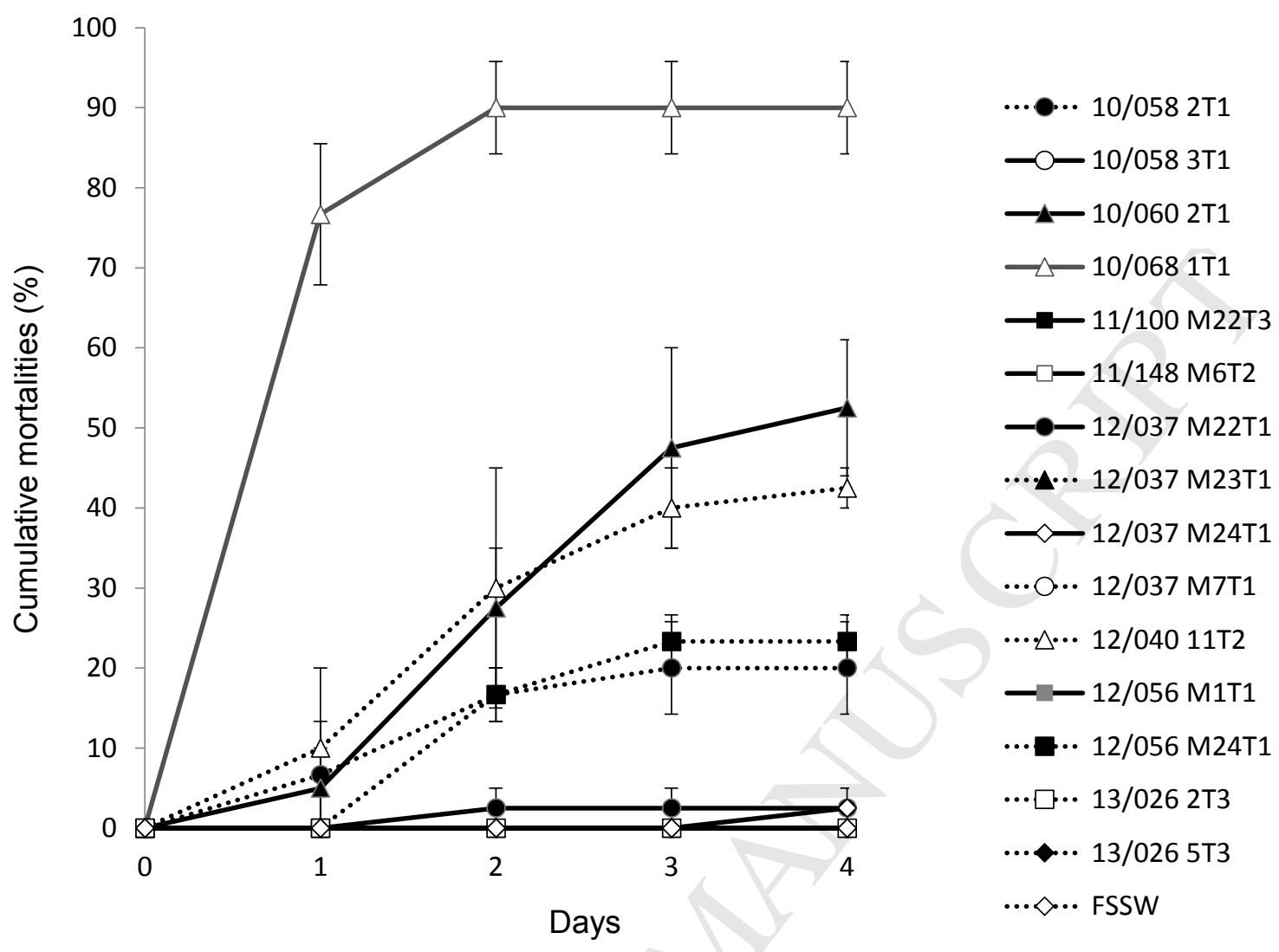




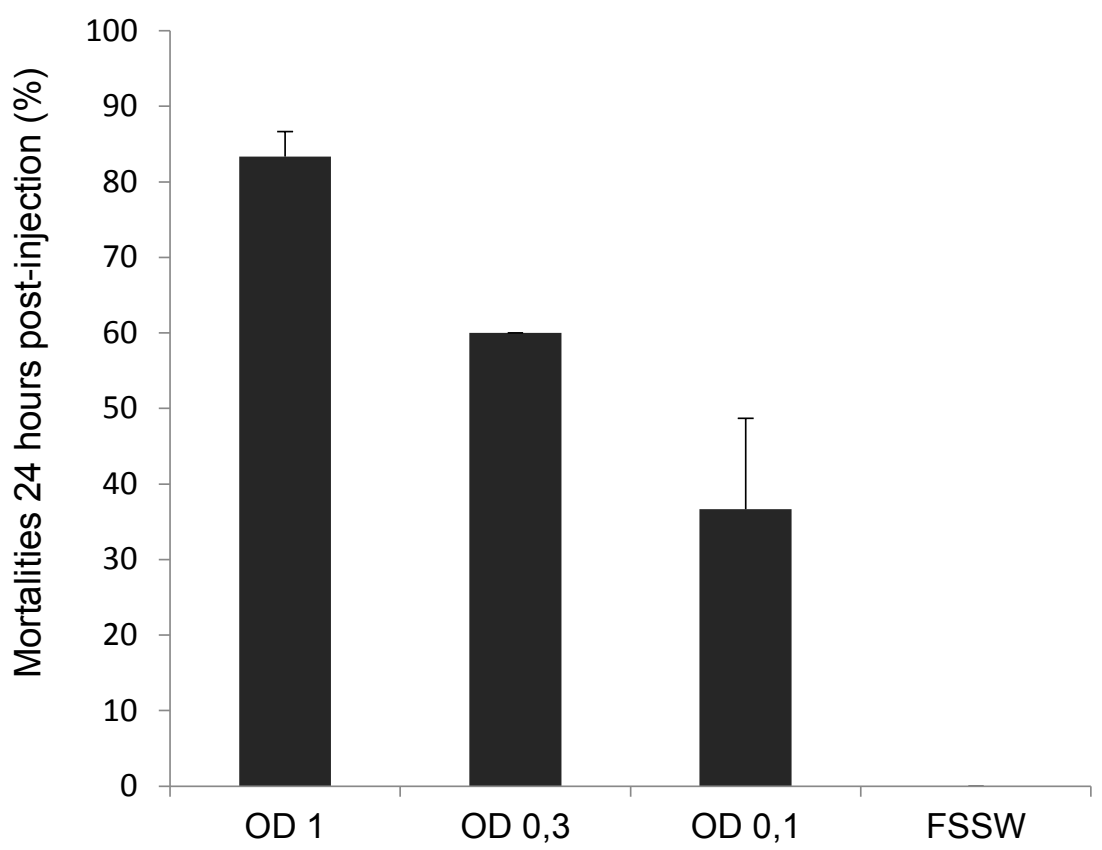




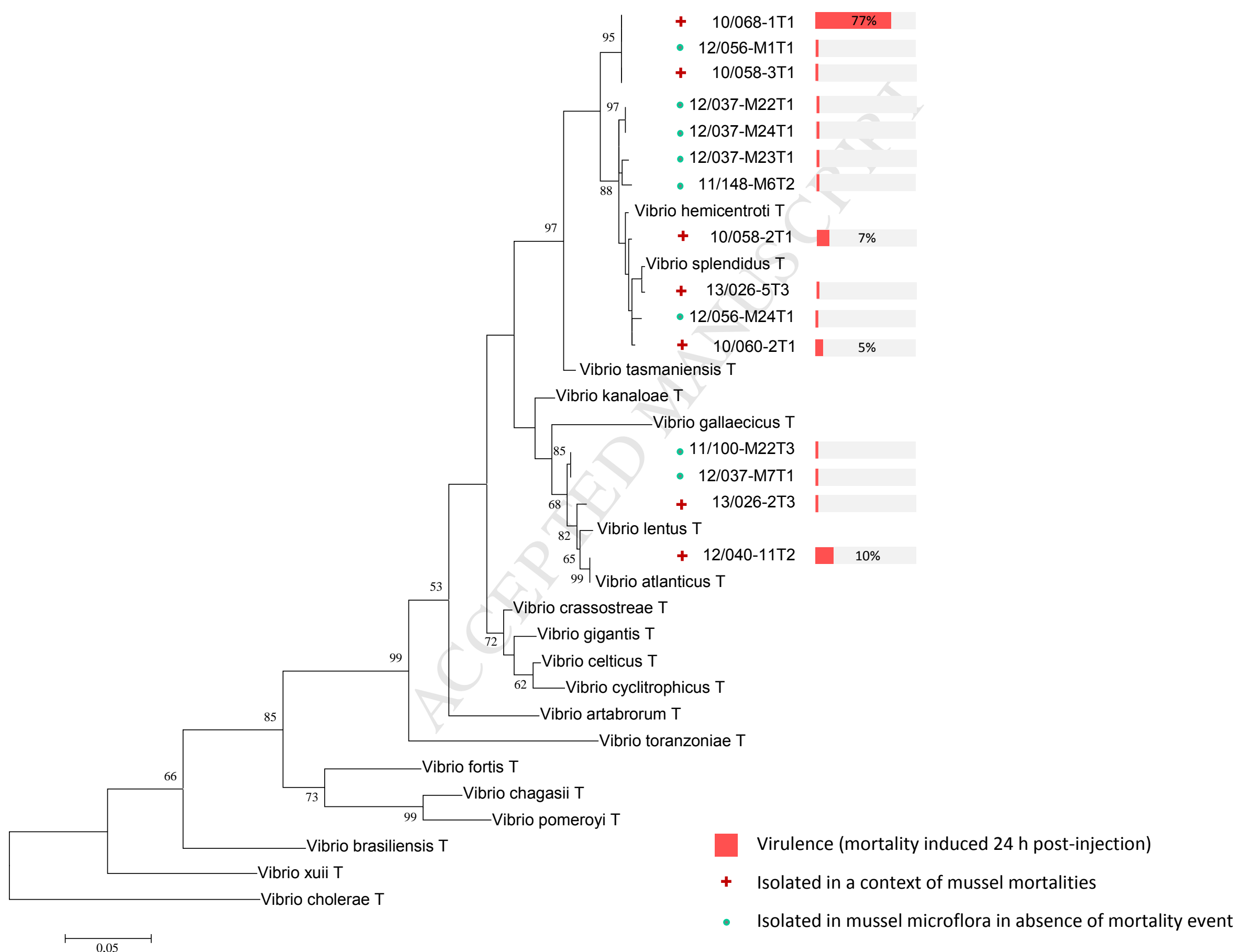


(a)

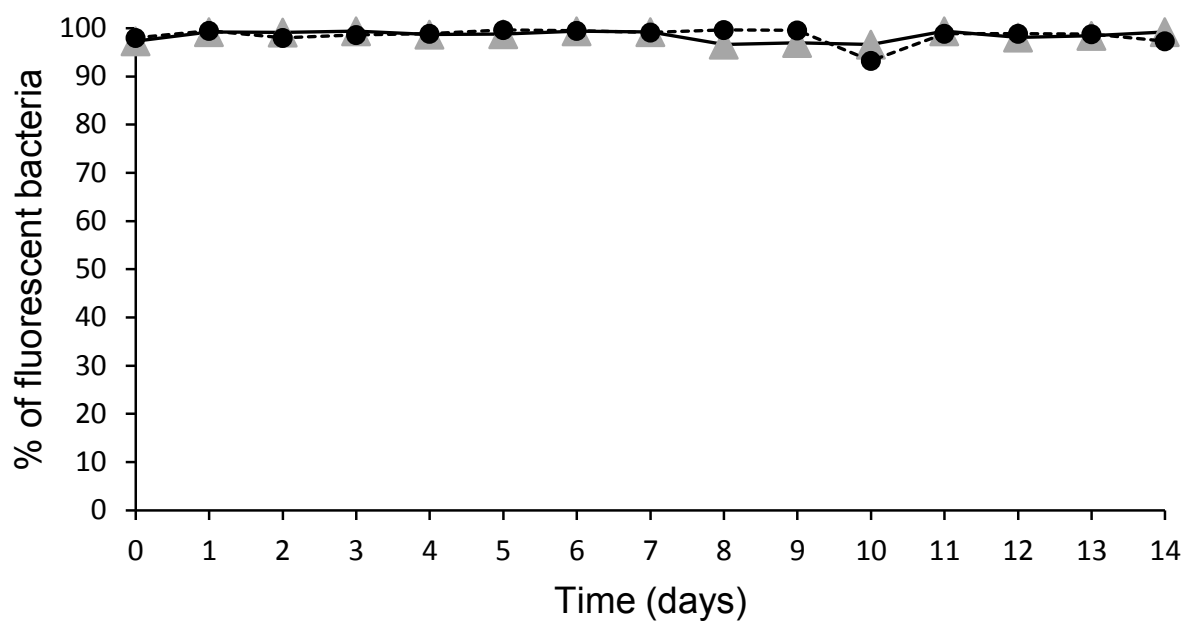

$\longrightarrow$ 10/068 1T1 GFP $\quad----12 / 056$ M24T1 GFP

(b)

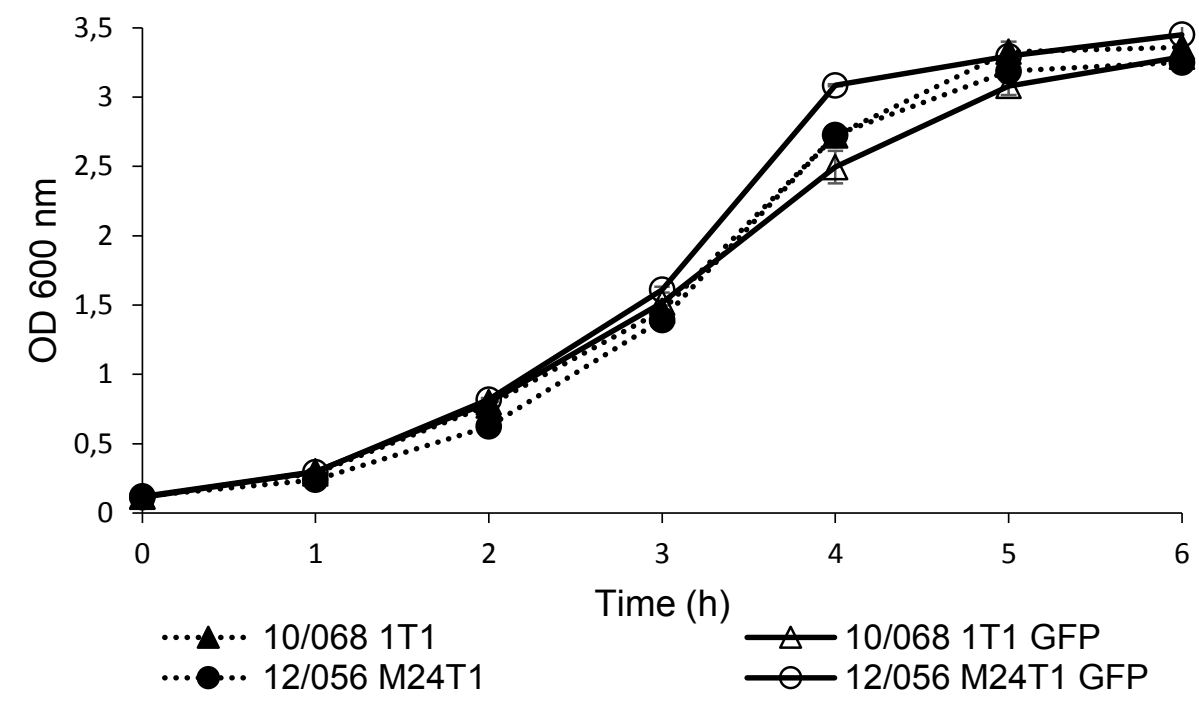

(c)

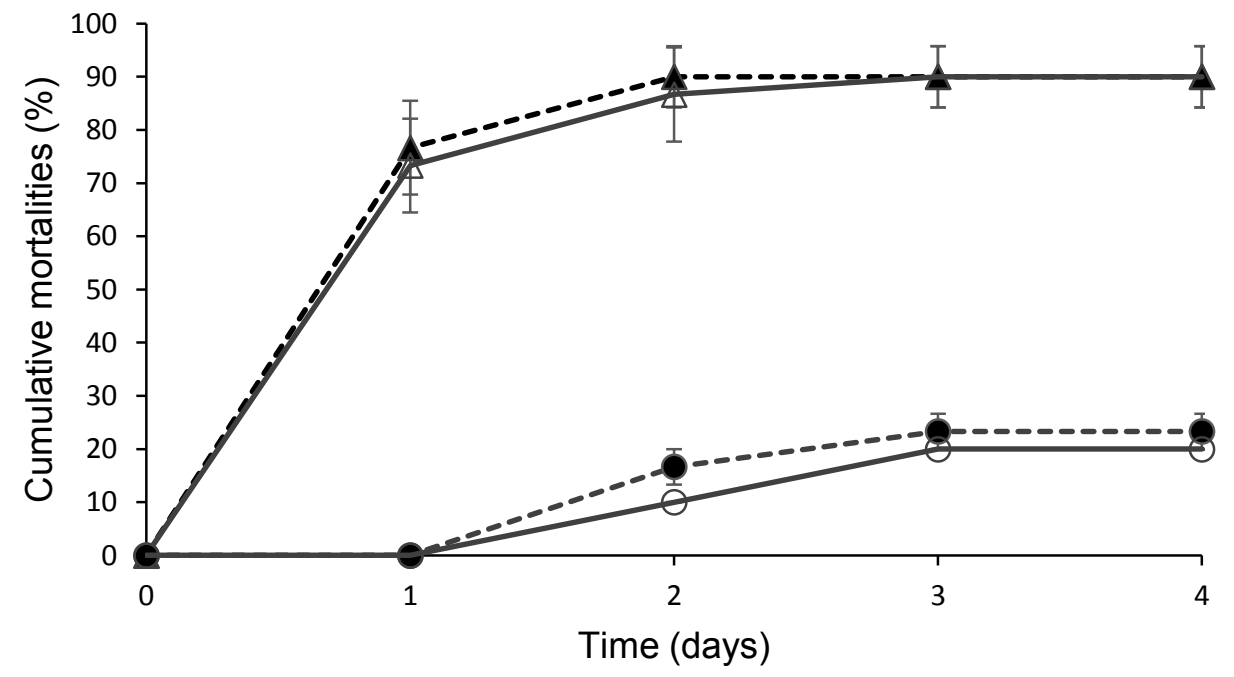

--\$-•-10/068 1T1

$\triangle 10 / 0681 \mathrm{~T} 1 \mathrm{GFP}$

- - 12/056 M24T1

-12/056 M24T1 GFP 


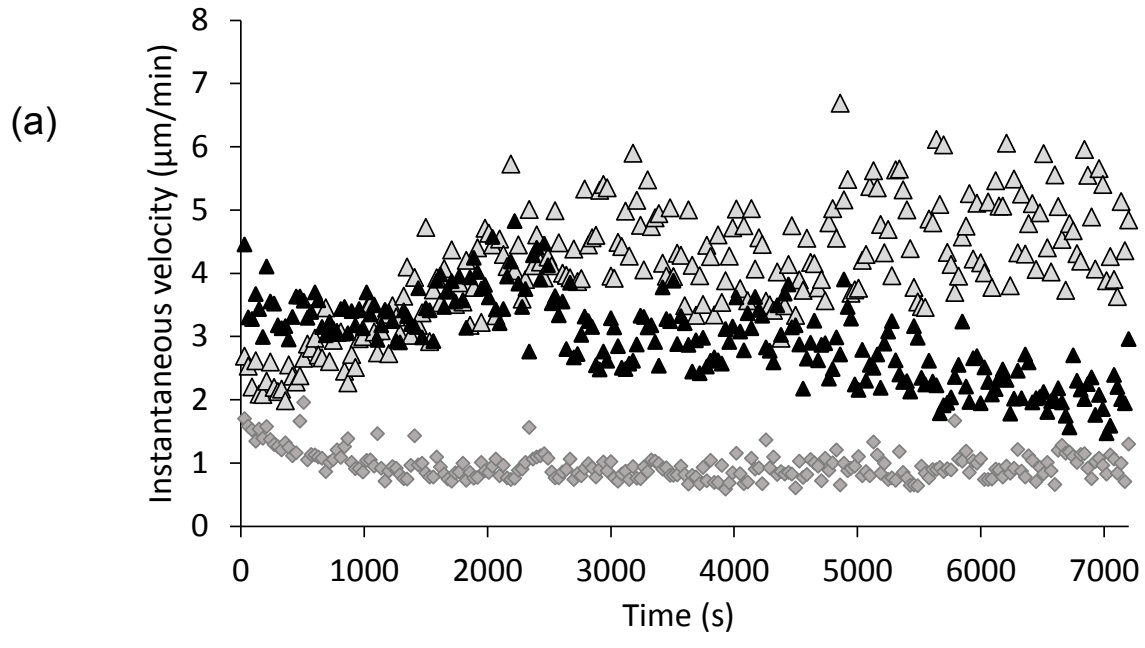

$\diamond$ Control $\triangle 12 / 056$ M24T1 $\Delta$ 10/068 1T1

(b)

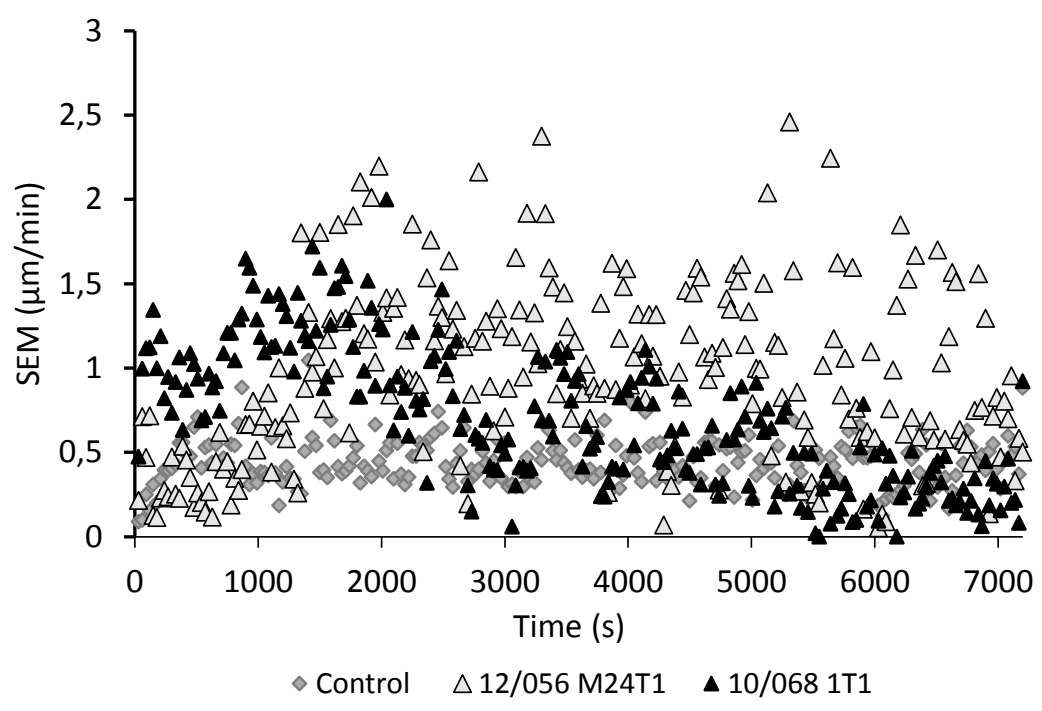


(a)

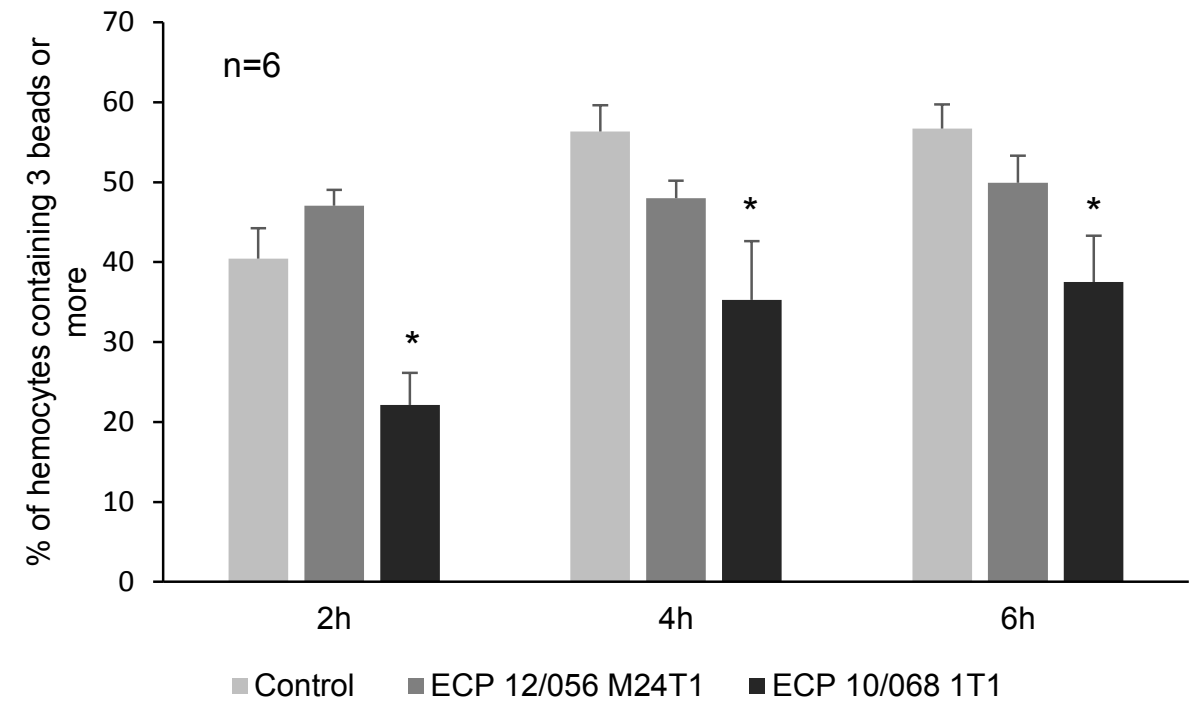

(b)
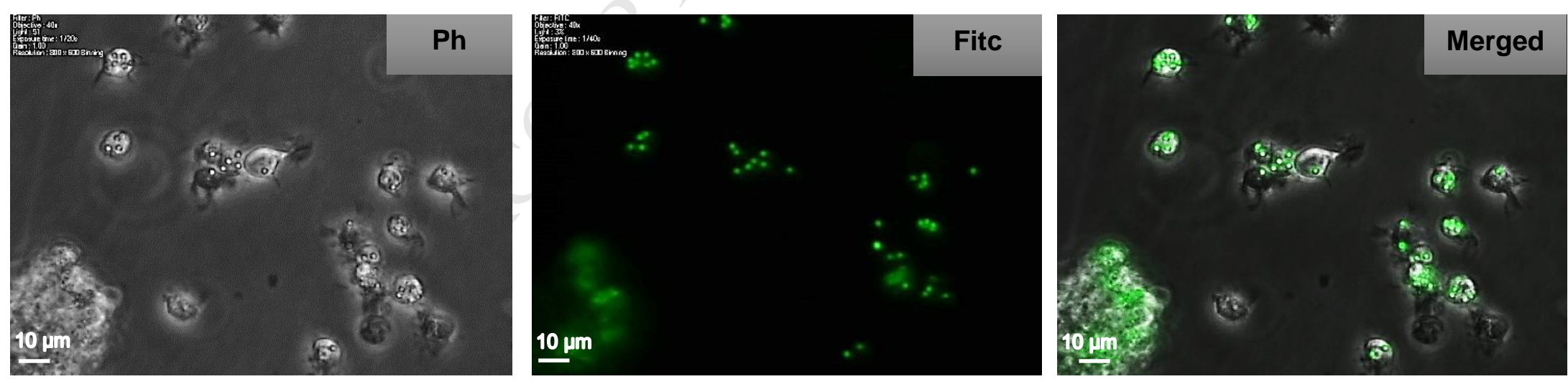
(a)

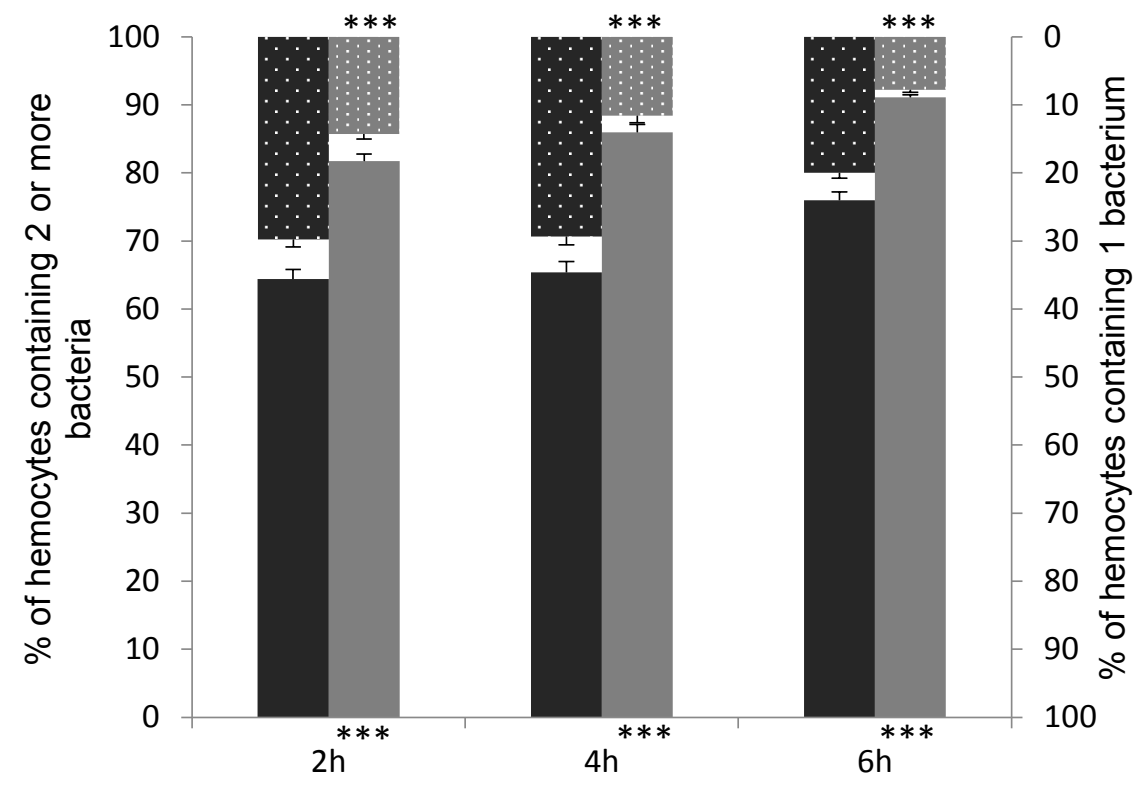

- 12/056 M24 T1

- 10/068 1T1

. 12/056 M24 T1

. $10 / 0681 T 1$

(b)
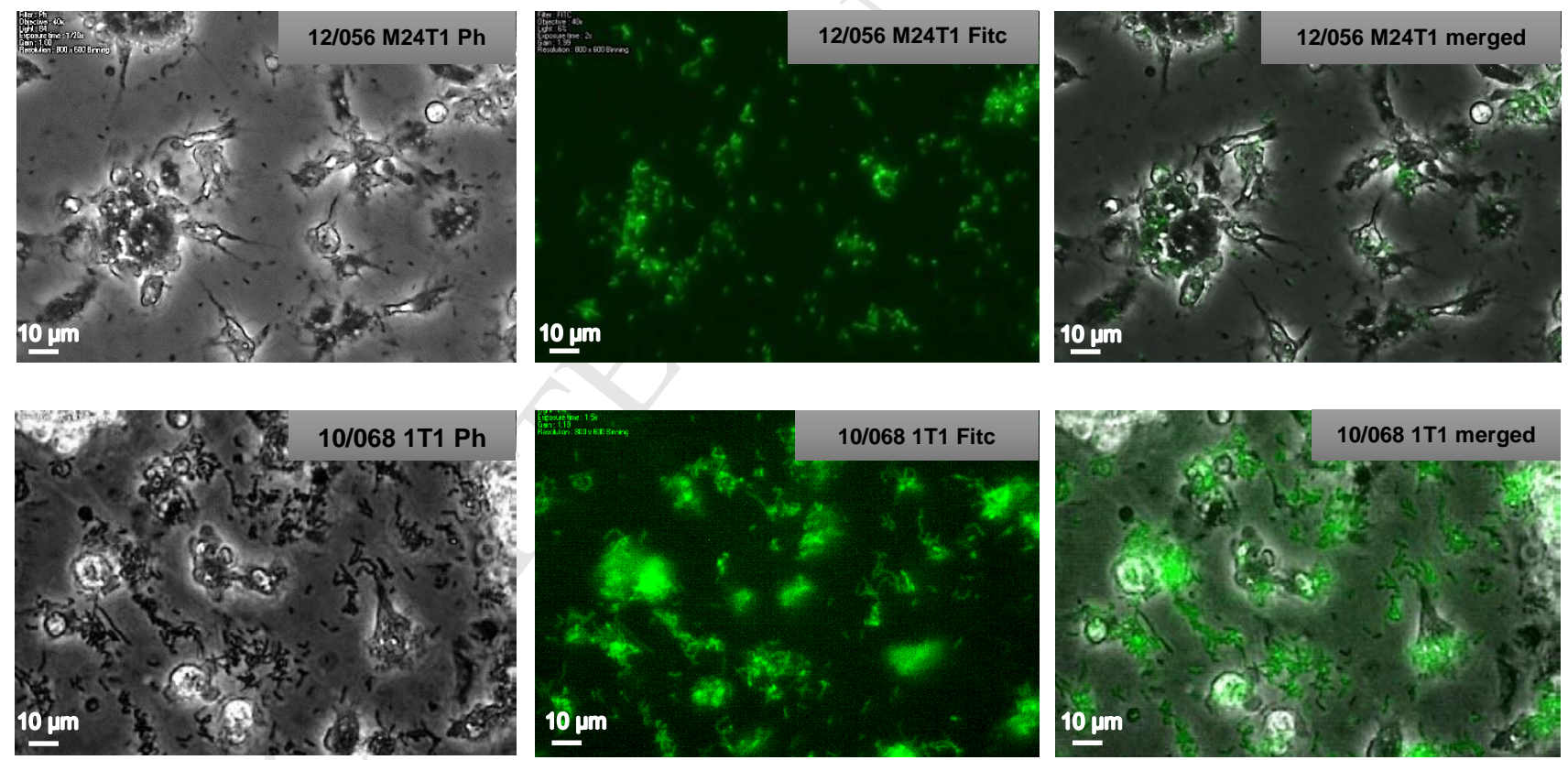


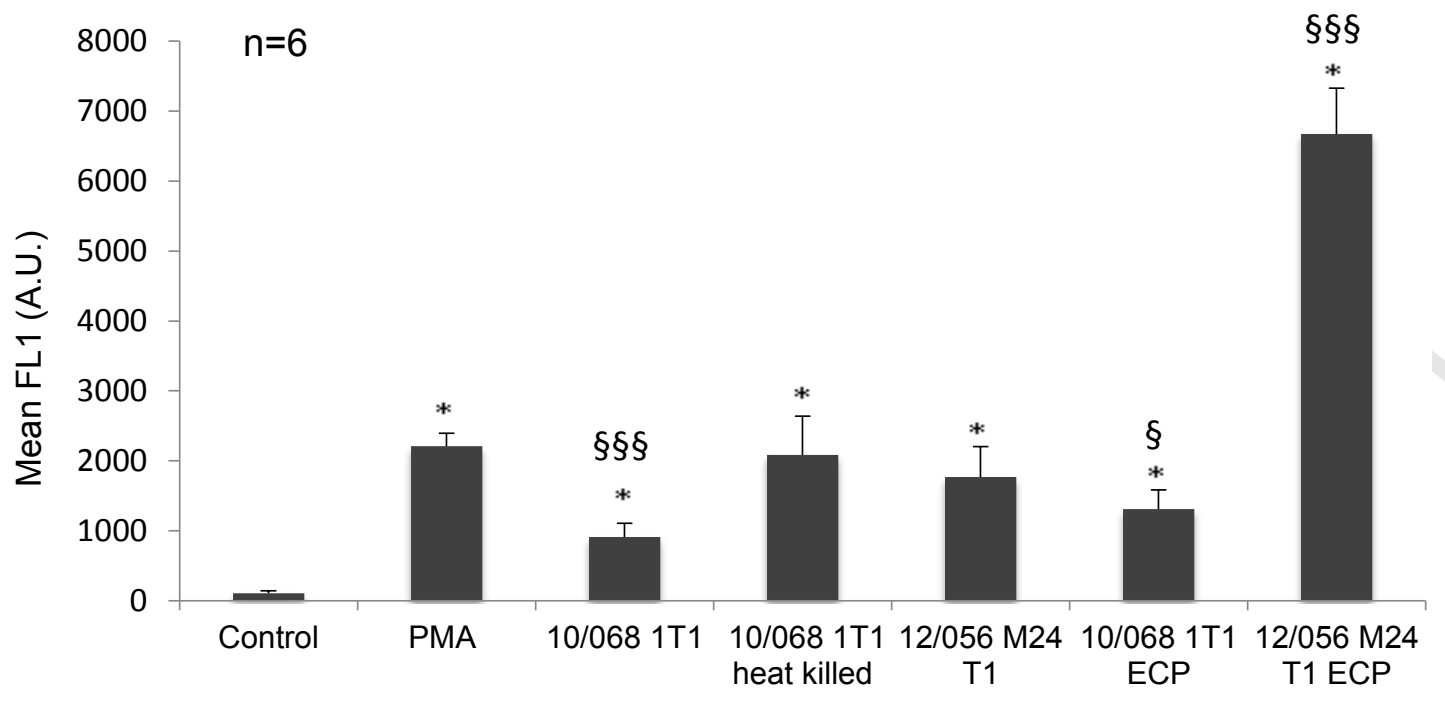

